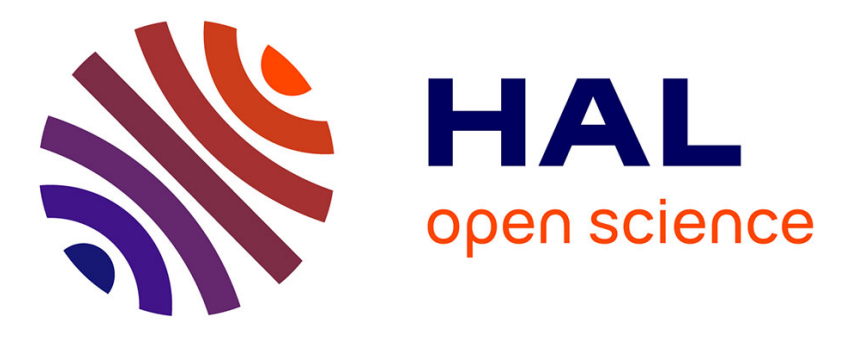

\title{
Vascular calcification: from pathophysiology to biomarkers
}

Séverine Evrard, Pierre Delanaye, Jean-Paul Cristol, Etienne Cavalier, J. Arnaud, Ph. Zaoui, M. Carlier, M. Laville, D. Fouque, Anne-Sophie Bargnoux, et al.

\section{To cite this version:}

Séverine Evrard, Pierre Delanaye, Jean-Paul Cristol, Etienne Cavalier, J. Arnaud, et al.. Vascular calcification: from pathophysiology to biomarkers. Clinica Chimica Acta, 2015, 438, pp.401 - 414. 10.1016/j.cca.2014.08.034 . hal-01756119

\section{HAL Id: hal-01756119 \\ https://hal.umontpellier.fr/hal-01756119}

Submitted on 2 Feb 2020

HAL is a multi-disciplinary open access archive for the deposit and dissemination of scientific research documents, whether they are published or not. The documents may come from teaching and research institutions in France or abroad, or from public or private research centers.
L'archive ouverte pluridisciplinaire HAL, est destinée au dépôt et à la diffusion de documents scientifiques de niveau recherche, publiés ou non, émanant des établissements d'enseignement et de recherche français ou étrangers, des laboratoires publics ou privés. 


\title{
Vascular calcification: from pathophysiology to biomarkers
}

\author{
Séverine Evrard ${ }^{\mathrm{a}}$, Pierre Delanaye ${ }^{\mathrm{b}}$, Said Kamel ${ }^{\mathrm{c}, \mathrm{d}}$, Jean-Paul Cristol ${ }^{\mathrm{e}}$, Etienne Cavalier ${ }^{\mathrm{a}, *}$, \\ On behalf of the SFBC/SN joined working group on vascular calcifications
} J. Arnaud ${ }^{1}$, Ph. Zaoui ${ }^{1}$, M.C. Carlier ${ }^{2}$, M. Laville ${ }^{2}$, D. Fouque ${ }^{2}$, E. Cavalier ${ }^{3}$, P. Delanaye ${ }^{3}$, J.P. Cristol ${ }^{4}$, A.S. Bargnoux ${ }^{4}$, S. Kamel ${ }^{5,6}$, Z. Massy ${ }^{6,7}$, D. Prié ${ }^{8}$, P. Urena-Torres ${ }^{8}$, J.C. Souberbielle ${ }^{8}$, A. Boutten ${ }^{9,10}$, A. Guérin ${ }^{11}$, T. Hannedouche ${ }^{12}$, G. Jean ${ }^{13}$, M.H. Lafage-Proust ${ }^{14}$, G. London ${ }^{15}$, L. Mercadal ${ }^{16}$, L. Pieroni ${ }^{17}$

${ }^{1} \mathrm{CHU}$ Grenoble, France

${ }^{2}$ CHU Lyon, France

${ }^{3}$ CHU Sart-Tilman, Liège, Belgium

${ }^{4}$ CHU Montpellier, France

${ }^{5}$ INSERM U1088, France

${ }^{6}$ CHU Amiens, France

${ }^{7}$ CHU Ambroise Paré, France

${ }^{8}$ Inserm/Université U 845, Paris, France

${ }^{9}$ APHP, France

${ }^{10}$ GH Paris Nord Val de Seine, France

${ }^{11} \mathrm{CH}$ de Manhes, France

${ }^{12}$ CHU Strasbourg, Ph Brunet CHU Marseille, France

${ }^{13}$ Nephrocare Tassin-Charcot, Lyon, France

${ }^{14}$ CHU St Etienne, France

${ }^{15}$ INSERM U970, Paris, France

${ }^{16}$ Pitié Salpétriere, Paris, France

${ }^{17} \mathrm{CH}$ Avignon, France

a Department of Clinical Chemistry, University of Liège, CHU Sart-Tilman, Liège, Belgium

bepartment of Nephrology, Dialysis and Hypertension, University of Liège, CHU Sart-Tilman, Liège, Belgium

${ }^{\mathrm{c}}$ Laboratoire de Biochimie, CHU Amiens, Amiens, France

d INSERM U1088, Université de Picardie Jules-Verne, Amiens, France

e Laboratoire de Biochimie, CHRU de Montpellier, Hôpital Lapeyronie, Montpellier, France

Keywords:

Vascular calcification

Fibroblast growth factor-23

Fetuin-A

Matrix Gla protein

Bone morphogenetic protein-2

Osteoprotegerin

\begin{abstract}
A B S T R A C T
The link between vascular calcification (VC) and increased mortality is now well established. Over time, as clinical importance of this phenomenon has begun to be fully considered, scientists have highlighted more and more physiopathological mechanisms and signaling pathways that underlie VC. Several conditions such as diabetes, dyslipidemia and renal diseases are undoubtedly identified as predisposing factors. But even if the process is better understood, many questions still remain unanswered. This review briefly develops the various theories that attempt to explain mineralization genesis. Nonetheless, the main purpose of the article is to provide a profile of the various existing biomarkers of VC. Indeed, in the past years, a lot of inhibitors and promoters, which form a dense and interconnected network, were identified. Given importance to assess and control mineralization process, a focusing on accumulated knowledge of each marker seemed to be necessary. Therefore, we tried to define their respective role in the physiopathology and how they can contribute to calcification risk assessment. Among these, Klotho/ fibroblast growth factor-23, fetuin-A, Matrix Gla protein, Bone morphogenetic protein-2, osteoprotegerin, osteopontin, osteonectin, osteocalcin, pyrophosphate and sclerostin are specifically discussed.
\end{abstract}

Abbreviations: 1,25 (OH) 2 D, 1,25-dihydroxyvitamin D; ALP, alkaline phosphatase; AVK, vitamin K antagonists; BAX, BCL2-associated X protein; BMDM, bone marrow-derived macrophage; BMP-2, bone morphogenetic protein-2; CAC, coronary artery calcifications; CAD, coronary artery disease; CaSR, calcium-sensing receptor; Cfba1/Runx2, core-binding factor subunit $1 \alpha /$ runt-related transcription factor 2; CKD, chronic kidney disease; cMGP, carboxylated MGP; CPP, calciprotein particles; dp-uc MGP, dephosphorylated uncarboxylated MGP; EPCs, endothelial progenitor cells; ePPi, extracellular PPi; Fet-A, fetuin-A; FGF-23, fibroblast growth factor-23; HD, hemodialysis; HIF-1 $\alpha$, hypoxia-inductible factor $1 \alpha$; MGP, matrix gla protein; MVs, matrix vesicles; MVSC, multipotent vascular stem cells; ND, non dialysis; OC, osteocalcin; ON, osteonectin; OPG, osteoprotegerin; OPN, osteopontin.

* Corresponding author at: Department of clinical chemistry, University of Liège, CHU Sart-Tilman, Domaine du Sart-Tilman, B-4000 Liège, Belgium. Tel.: + $3243668822,+324366$ 76 92; fax:+3243668823.

E-mail address: etienne.cavalier@chu.ulg.ac.be (E. Cavalier). 


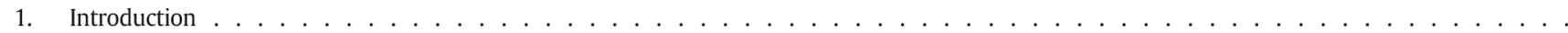

2. Overview of vascular calcification : from genetics to osteoblastic differentiation

2.1. Genetic predisposition . . . . . . . . . . . . . . . . . . . . . . . . . . . . . . 402

2.2. Osteoblastic differentiation . . . . . . . . . . . . . . . . . . . . . . . . . . . . . . . 402

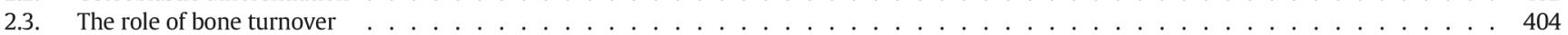

2.3.1. Low turnover . . . . . . . . . . . . . . . . . . . . . . . . . . . . . . . . 404

2.3.2. High turnover . . . . . . . . . . . . . . . . . . . . . . . . . . . . . . . 404

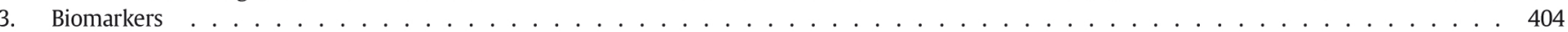

3.1. Fibroblast growth factor-23 (Fgf-23) and Klotho . . . . . . . . . . . . . . . . . . . . . . . . . . . . . . . . . . . . 404

3.2. Fetuin-A (Fet-A) . . . . . . . . . . . . . . . . . . . . . . . . . . . . 405

3.3. Matrix Gla protein (MGP) . . . . . . . . . . . . . . . . . . . . . . . . . . . . . . . . . 406

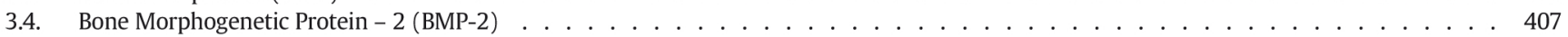

3.5. Osteoprotegerin $(\mathrm{O})$ and RANKL/Rank axis . . . . . . . . . . . . . . . . . . . . . . . . . . . . . . . . 407

3.6. Osteopontin $(\mathrm{OPN})$. . . . . . . . . . . . . . . . . . . . . . . . . . . . . . . . . . . 408

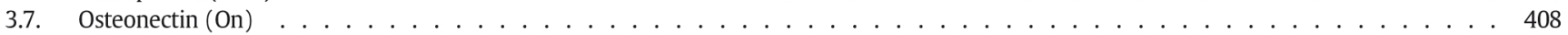

3.8. Osteocalcin $(\mathrm{Oc}) \ldots \ldots \ldots$

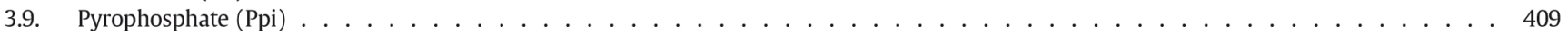

3.10. Sclerostin . . . . . . . . . . . . . . . . . . . . . . . . . . . . . . . . . 409

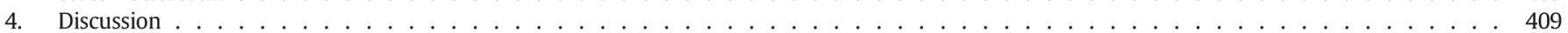

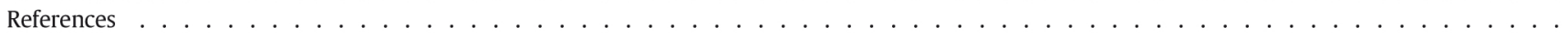

\section{Introduction}

Occurrence of vascular calcification (VC) is not new. Arterial calcification has been discovered in the "Iceman" who lived 5000 years ago [1] and scientists had already paid attention to this phenomenon - and to its relation with renal disease - in the 19th Century[2]. VC increases with age and is notably dysregulated in diabetes, dyslipidemia, renal disease and hypertension [3]. Bone formation involves hydroxyapatite [Ca10(PO4)6(OH)2] crystals, whose development begins in matrix vesicles (MVs) that bud from osteoblasts. Vascular smooth muscle cells (VSMCs) that have undergone osteoblast differentiation are also able to release similar vesicles with shared protein content [4]. Such differentiation is restrained or inhibited under normal conditions and there is a balance with osteoclast differentiation experienced by monocytes and macrophages within the vascular wall. Moreover, the reaction which allows crystal growth is thermodynamically unfavorable and is inhibited by pyrophosphate [3]. In some situations, physiological balance is broken and VC is able to progress.

For a long time, VC has been considered as an ageing fatality. Despite the fact we cannot completely deny the link with ageing, VC is no longer regarded as a passive process. Today, it is considered as an actively regulated and complex process that remains not completely understood. We know that many dynamic changes can trigger or promote VC and a lot of theories emerged during the last two decades. We will describe hereafter some of the physiopathological mechanisms. It is important to underline that these different mechanisms are not mutually exclusive [5].

\section{Overview of vascular calcification : from genetics to osteoblastic differentiation}

\subsection{Genetic predisposition}

As shown in Fig. 1, genetic predisposition certainly plays an important role in the genesis of this phenomenon. According to Rutsch et al., [6], $40-50 \%$ of cases of coronary calcification can be attributed to genetics. Genome-wide association studies have identified several loci linked to coronary arterial calcification, like 6p21.3, 6p24, 10q21.3 and 9p21 [3,7-9]. Interestingly, some of these regions also appear to be related to coronary atherosclerosis [7] and the $6 \mathrm{p} 24$ locus is also linked to myocardial infarction [10]. An implication of several single polymorphisms located at 9p21 locus near the cyclin genes has been suggested in the genesis of pathology [9]. These genes encode cyclins that may be broadly linked to cellular senescence and inflammation but the accurate causative DNA sequences remains debated [3].

Genes ENPP1 and NT5E are respectively implicated in infancy and idiopathic VC. The first one encodes a protein which transforms ATP to adenosine and pyrophosphate (PPi, inhibitor of calcification) whereas the second one converts AMP into adenosine and inorganic phosphate ( $\mathrm{Pi}$, accelerator of mineralization). The VC phenotype caused by mutations in these genes underlines the role of PPi and Pi in pathogenesis [3]. Mutations in ABCC6, a gene encoding a nucleoside-sensitive transporter, have also been linked to hereditary calcification. Alternative action of ABCC6 may include deficient hepatic production of inhibitory factor of matrix Gla protein (MGP), an important inhibitor of calcification [3,11].

\subsection{Osteoblastic differentiation}

One major mechanism in the development of VCs is similar to that of bone formation. First, vascular smooth muscle cells (VSMCs) undergo osteogenic differentiation into phenotypically distinct osteoblast-like cells $[5,12]$. In the case of renal failure, phosphate plays a key role in this mechanism $[13,14]$. In vitro, high extracellular phosphate concentrations induce a rise in intracellular phosphate concentration which is actively mediated by Pit- 1 , a sodium dependent phosphate cotransporter $[14,15]$. This increasing phosphate concentration in the VSMC induces a phenotypic switch of VSMCs into osteoblast-like cells $[5,14,16]$. The protein Cfba1/Runx2 (core-binding factor subunit $1 \alpha /$ runt-related transcription factor 2 ) is a specific and indispensable transcriptional regulator for this osteoblastic differentiation. Its expression is also enhanced with high extracellular phosphate $[14,16,17]$. These "new" cells will express alkaline phosphatase (ALP), secrete, under the control of Cfba-1, bone-associated proteins (such as osteopontin [18], collagen type 1, osteoprotegerin, bone morphogenic protein-2 and osteocalcin $[14,19]$ ) and release mineralization-competent MVs in the extracellular matrix $[13,14,20]$. VSMCs release MVs under normal physiological conditions and these MVs are protected from mineralization by the presence of calcification inhibitors. Under pathological conditions, a combination of factors makes the MVs "mineralization competent" [21]. Moreover, an increase of intracellular phosphate level mediated by $\mathrm{Na} / \mathrm{Pi}$ transporter is thought to induce VSMC apoptosis 


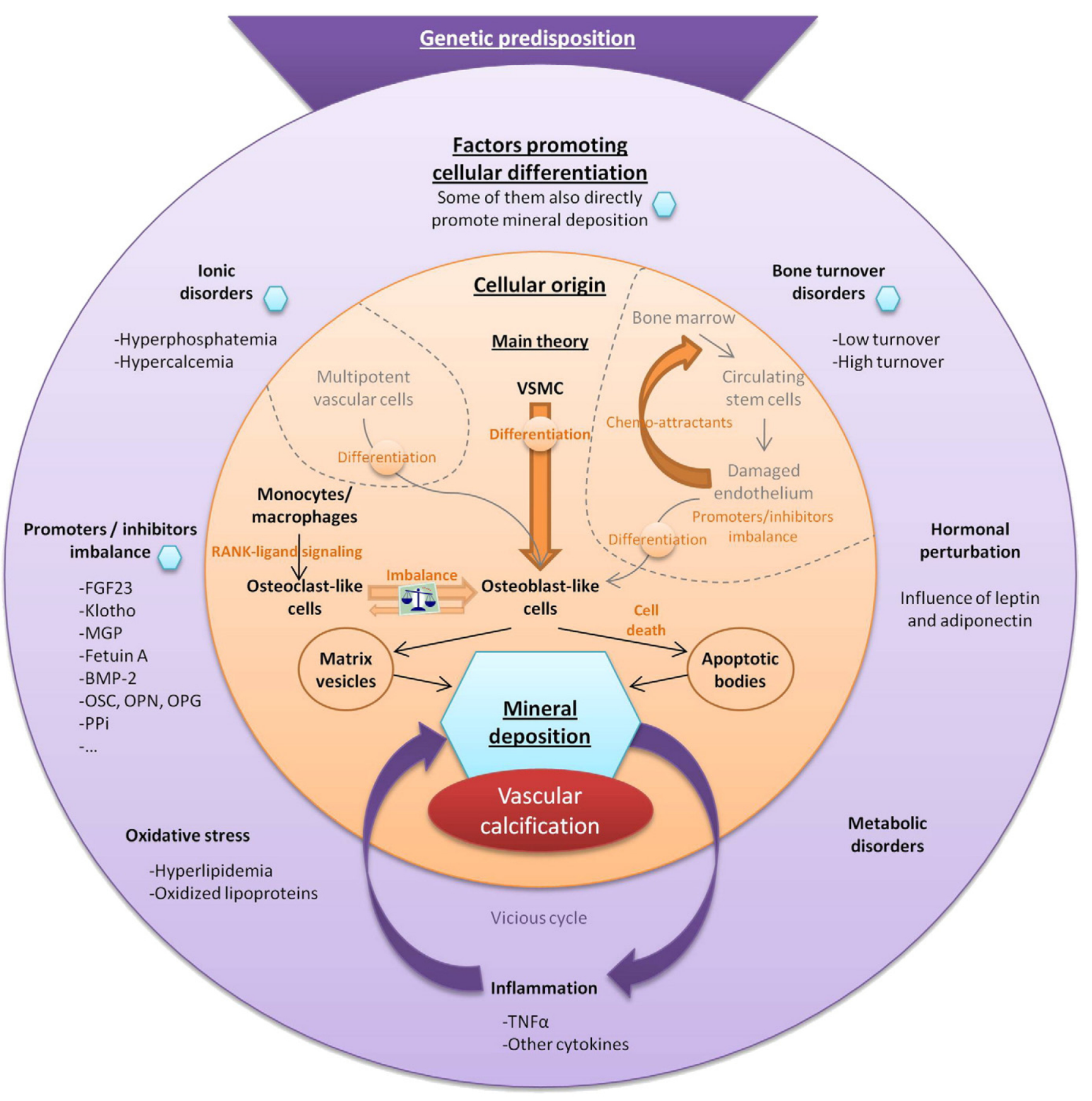

Fig. 1. Physiopathological mechanisms which promote cellular differentiation and mineral deposition.

through an unclear process that possibly involves a disruption in mitochondrial metabolism [22]. Some studies suggest that apoptosis leads to calcification [23-26]. The MVs, in which proapoptotic factor BAX (BCL2-associated X protein) have been identified [26], may be remnants of apoptotic cells. As MVs have the capacity to concentrate and crystallize calcium, apoptosis could be a key regulator of VC [22].

More recently, a different point of view has emerged according to which phenotypically distinct osteoblast-like cells might originate from stem cells rather than VSMCs. A new mechanism called "Circulating cell theory", suggesting an active role for circulating cells arising from sources such as bone marrow, has been postulated to contribute towards VC. Under the influence of chemo-attractants (released by damaged endothelium for instance), these bone marker-positive cells may home to diseased arteries. Under pathologic conditions such as an imbalance between promoters and inhibitors of VC, this population may further undergo osteogenic differentiation in the lesions, which could promote vessel mineralization [27]. Another recent study has also claimed that multipotent vascular stem cells (MVSC) present in blood vessel wall might differentiate into osteoblast-like cells [28]. Nevertheless, this point of view is still very controversial.

Although the role of phosphate is well established in osteoblastic differentiation process, many other factors can influence this phenotype conversion and accurate causal mechanisms remained not completely understood. Under normal conditions, VSMCs produce endogenous inhibitors of calcification such as matrix gla protein (MGP), osteopontin, osteoprotegerin and pyrophosphate [29]. A long-term exposure of VSMCs to a variety of stresses can overwhelm the action of these inhibitors and induce differentiation [21]. Among these chronic stresses, ionic disorders (especially hyperphosphatemia and hypercalcemia) are incriminated but inflammation, hormonal perturbation, metabolic disorders and oxidative stress can also lead to VC. Oxidative stress in VSMCs, in particular generated by hyperlipidemia and oxidized 
lipoproteins or uremic milieu[30], causes the expression of runx2 [31], osterix and govers Wnt signaling [32], leading to osteogenic differentiation. Inflammatory cytokines, such as TNF- $\alpha$, can also induce calcification via Msx2/Wnt/ $\beta$-catenin pathway [33]. In support of that, calcium deposits colocalize with inflammatory cells in vitro [34, 35 ] and in vivo [36]. Moreover, it has been suggested that mineral crystals may themselves be pro-inflammatory, creating a vicious cycle of inflammation and calcification $[37,38]$. The receptor for advanced glycation endproducts (RAGE) endogenously expressed in endothelial cells and its ligands (in which S100 family proteins are found), are also known to be involved in atherosclerotic formation and VC. It has been suggested that galectin-3 and RAGE modulate vascular osteogenesis in part via Wnt/ß-catenin signaling [39]. Several trials have shown a raise in serum levels of $\$ 100 /$ calgranulins in vascular disease $[40,41]$. Thereby, S100 proteins could be a potential biomarker and therapeutic target to develop [3]. Involved in the control of both parathyroid hormone (PTH) and calcitonin secretion, the calcium-sensing receptor (CaSR) is a G protein-coupled cell surface receptor that is able to sense extracellular calcium ions. Evidences have been provided to demonstrate that a decrease in the CaSR protein expression in the vasculature is directly involved in the development of VC [42,43]. It is of particular interest to note that calcimimetics, which are allosteric drug compounds that selectively target the CaSR, decrease VC at least in part through local control of the CaSR expression in VSMC $[44,45]$. However, so far, the mechanism whereby the CaSR exert its protective effect remains largely unknown. Hormones have pleiotropic effects on calcific vasculopathy. For example, the adipose-derived factor, leptin, promotes VC in vitro [46] and in vivo [47]. Adiponectin-deficient mice have increased vascular calcification [48]. The influence of PTH is part of bone turnover process and is discussed further. A disruption between promoters and inhibitors can also generate VC. Moreover, similar to bone formation, there might exist a balance between VC and its resorption. Indeed, monocytes and macrophages contained in the calcified wall can differentiate into an osteoclast-like phenotype and counteracts the action of VSMCs that have undergone osteoblast differentiation [49]. Hyperphosphatemia would disadvantage osteoclast phenotype by down-regulating RANK ligand-induced signaling [50] but this is not clear whether osteoclast-like cells can really counteract VC or solely witness vascular remodeling process.

All these modifications will favour for an optimal microenvironment for hydroxyapatite formation and calcification. Similar osteogenic differentiation is also observed, in vivo, in animal and human uremic models $[12,16,51]$.

\subsection{The role of bone turnover}

As calcium and phosphorus have a pivotal role in the pathogenesis of $\mathrm{VC}$, it is not surprising that bone-turnover disturbances can enhance VC because bone is the most important reserve of calcium and phosphorus and could act as a buffer [52]. Some authors have written about the "bone-vascular" axis. The link between "low bone turnover" and risk of VCs is likely better illustrated by the current literature. However, the two "theories" of low and high turnover are not excluding each other in a context of "bone as a calcium-phosphorus buffer" [53].

\subsubsection{Low turnover}

In the first article measuring VCs, Braun et al. have already shown that coronary calcifications are inversely correlated with bone mass [54]. Probably the most interesting study on this topic has been published in 2004 by London et al. These authors have actually compared VCs by plain radiography with bone histomorphometry in 58 dialysis patients. They found that a high calcification score is independently associated with histomorphometry suggestive of low bone turnover (or a dynamic bone)[55]. One complementary study from the same group especially underlined that calcium load is particularly deleterious, in terms of VCs, for these patients with low bone turnover [56]. Studying both coronary calcifications and bone histomorphometry in 101 dialysis patients, Barreto et al. also found an inverse correlation between calcium score and bone trabecular volume and trabecular thickness in an univariate analysis [57]. In 2009, Adragao et al. studied the relationship between bone histomorphometry and coronary calcifications in 38 dialysis patients. Contrary to precedent trials, low bone turnover was not associated with calcifications. However, lower bone volume was a risk factor for coronary calcification [58].

\subsubsection{High turnover}

The epidemiological link observed by some authors between PTH and CV mortality in dialysis patients has already been mentioned [59-62]. Coen et al. have demonstrated a relationship between high PTH levels (especially very high levels) and coronary calcifications $[63,64]$. Even if specific PTH fragments (1-34 PTH) have been shown to inhibit VCs in an animal model [65], Neves et al. have shown, in a model of parathyroidectomized rats with chronic kidney disease (CKD), that perfusion of PTH, per se, could induce VCs [66].

In this review, we aim to provide a profile of the various existing biomarkers of VC. We will try to determine the respective role they play in the physiopathology and how they can contribute to calcification risk assessment.

\section{Biomarkers}

\subsection{Fibroblast growth factor-23 (Fgf-23) and Klotho}

Fig. 2. FGF-23 is an approximately $30 \mathrm{kDA}$ protein released by bone that requires the presence of the cofactor Klohto for its classical effects. FGF-23 promotes phosphate excretion by reducing its proximal re-absorption by reducing the expression of NPT2a and NPT2c mRNA, sodium/phosphate transporters [67]. Although the administration of 1,25-dihydroxyvitamin $\mathrm{D}(1,25-(\mathrm{OH}) 2 \mathrm{D})$ increases its circulating rate, FGF-23 levels also reduce $1 \alpha$-hydroxylase activity, which decreases conversion of calcidiol into its active form, 1,25- $(\mathrm{OH}) 2 \mathrm{D}$ and upregulates 24 -hydroxylase, which in turn converts $1,25-(\mathrm{OH}) 2 \mathrm{D}$ into more hydrophilic metabolites with lesser biological activity [68]. Thereby, gastrointestinal absorption of calcium and phosphate is reduced. In parathyroid glands, FGF23 decreases PTH secretion and parathyroid cell proliferation [69]. FGF-23 null mice develop hypercalcitriolemia and VC. The correction of hypercalcitriolemia improves survival but has no effect on VC. On the other side, poor phosphate diet leads to a complete normalization of the phenotype, suggesting that phosphate plays a major role in calcification abnormalities $[67,70]$. From this point of view, FGF-23 is more a hall marker of VC rather than a real actor.

However, it has been suggested that FGF-23 could actively participate in VC, perhaps by Klotho-independent functions [22,71]. Indeed, FGF-23 also induces left ventricular hypertrophy via FGFR-dependant, but Klotho independent, effects on cardiac myocytes [72]. This finding raises the possibility that elevated FGF-23 levels in CKD may also contribute to other forms of subclinical cardiovascular injury, such as VC [73]. A correlation between higher serum FGF-23 levels, mortality and $\mathrm{VC}$, regardless of the serum phosphate levels, has been confirmed by several studies [74-82]. However, a recent study from Scialla et al. [73] has challenged this point of view. In this translational study, the association between FGF23, serum phosphate and calcification of the coronary arteries and thoracic aorta has been studied in a sample of 1501 individuals. In contrast to serum phosphate, FGF23 was not associated with arterial calcification. In hemodialysis (HD) patients, Lee et al. [83] have not found a correlation between calcification and FGF23 levels either. Further studies are required in order to examine whether FGF23 may have a direct effect on progression of calcification.

The elevation of serum FGF-23 is a common feature in CKD. It appears that the massive elevations in FGF-23 levels in CKD reflect both increased secretion and decreased removal from circulation. FGF23 may be a compensatory phenomenon to the phosphate retention 


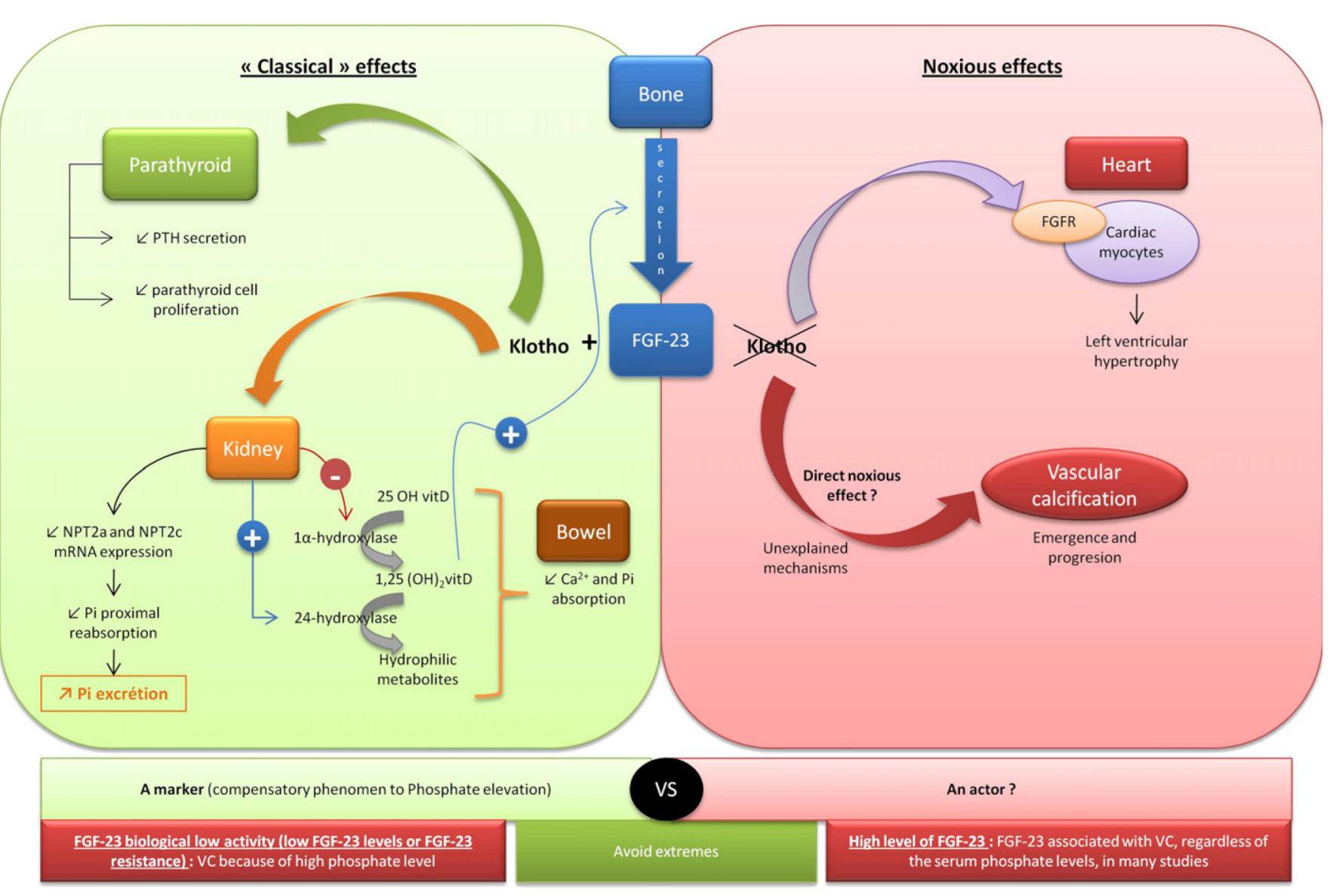

Fig. 2. Suspected duality of FGF23 effects.

seen in CKD [84]. In agreement with this hypothesis, FGF-23 was associated only with high coronary artery calcifications (CAC) (400) but not with moderate CAC (100-400) in a cohort of CKD patients[85]. Active vitamin D therapy may also contribute to the increased levels of FGF-23. Although the mechanistic link remains to be explained, FGF-23 may serve as a novel risk marker for the cardiovascular mortality in CKD [68]. In patients with coronary artery disease (CAD), the same independent link between FGF-23 and mortality has been demonstrated [84].

In contrast to FGF23, Klotho excess has never been shown to be noxious [86]. Klotho is a 1014 amino acids protein which is expressed on cell surface. It comprises a long extracellular queue, a transmembrane domain and a short intracellular portion [87]. Given the moderate FGF-23 affinity for its receptor, Klotho is needed to strengthen the link between the two entities. It thus increases FGF-23 ability to induce phosphorylation and signal transduction. This discovery emerged from the observation that either FGF-23 or Klotho knock-out mice resulted to the same phenotype [88]. As filtration rate decreases in CKD patients, Klotho expression is reduced and FGF-23 levels enhanced. This increase might represent an adaptation to Klotho diminution, also known as "FGF-23 resistance", or hyperphosphatemia [87]. Interestingly, Klotho levels are up-regulated by vitamin D receptor agonists (calcitriol or paricalcitol) in CKD mice submitted to a high phosphate diet. These mice show half less calcification than those who did not receive therapy. Phosphaturia is increased whereas phosphatemia and FGF-23 levels are lowered [89]. Klotho is expressed in a limited number of organs, including kidney and parathyroid gland. In addition to its membrane form, Klotho is also expressed in two soluble forms: one coming from cleavage of the membrane form and the other coming from an alternative splicing [87]. Membrane-anchored and soluble Klotho proteins seem to have distinct functions. Membrane Klotho mediates FGF-23 effects mentioned above whereas soluble Klotho is a pleiotropic protein functioning as an endocrine factor with a multitude of renal and extrarenal actions. Among these effects, anti-apoptotic, anti-oxidative, anti-Wnt signaling actions or modulation of renal ion channels are assumed [90]. In contrast, vascular Klotho deficiency favors the development of arterial calcification and mediates resistance to beneficial vascular effects of FGF23 [86].

\subsection{Fetuin-A (Fet-A)}

Fig. 3. Fet-A, a 59-kDa glycoprotein, is a potent calcification inhibitor produced by the liver that possess a systemic action. Serum Fet-A concentrations are decreased in dialysis patients compared with healthy controls $[91,92]$. The accurate mechanism is still hypothetical, but is probably related to chronic inflammation, as Fet-A is a negative acute phase reactant [93].

Its calcification inhibitory action is powerful and illustrated by knock-out mice developing severe extraosseous calcifications [94]. In this murine model, the aorta remains free from calcifications. However, CKD and high phosphate diet induce severe aorta calcifications in these knock-out mice [95]. Fet-A is thought to inhibit calcification by binding early calcium phosphate crystals and by inhibiting crystal growth and mineral deposition. This could be facilitated by the formation of large calciprotein particles $[96,97]$. Indeed, the accumulation of naked calcium phosphate crystals is responsible for extraosseous calcification and causes inflammation. These crystals are usually digested by the cells of the reticuloendothelial system such as macrophages. In contact with the crystals, macrophages secrete proinflammatory cytokines and undergo more apoptosis. The formation of fetuin-A calciprotein particles (CPP) facilitates the clearance of these crystals and thereby reduces their negative impact. Fet-A likely plays a very important role in the stabilization of these complexes and reduces the inflammatory response. 


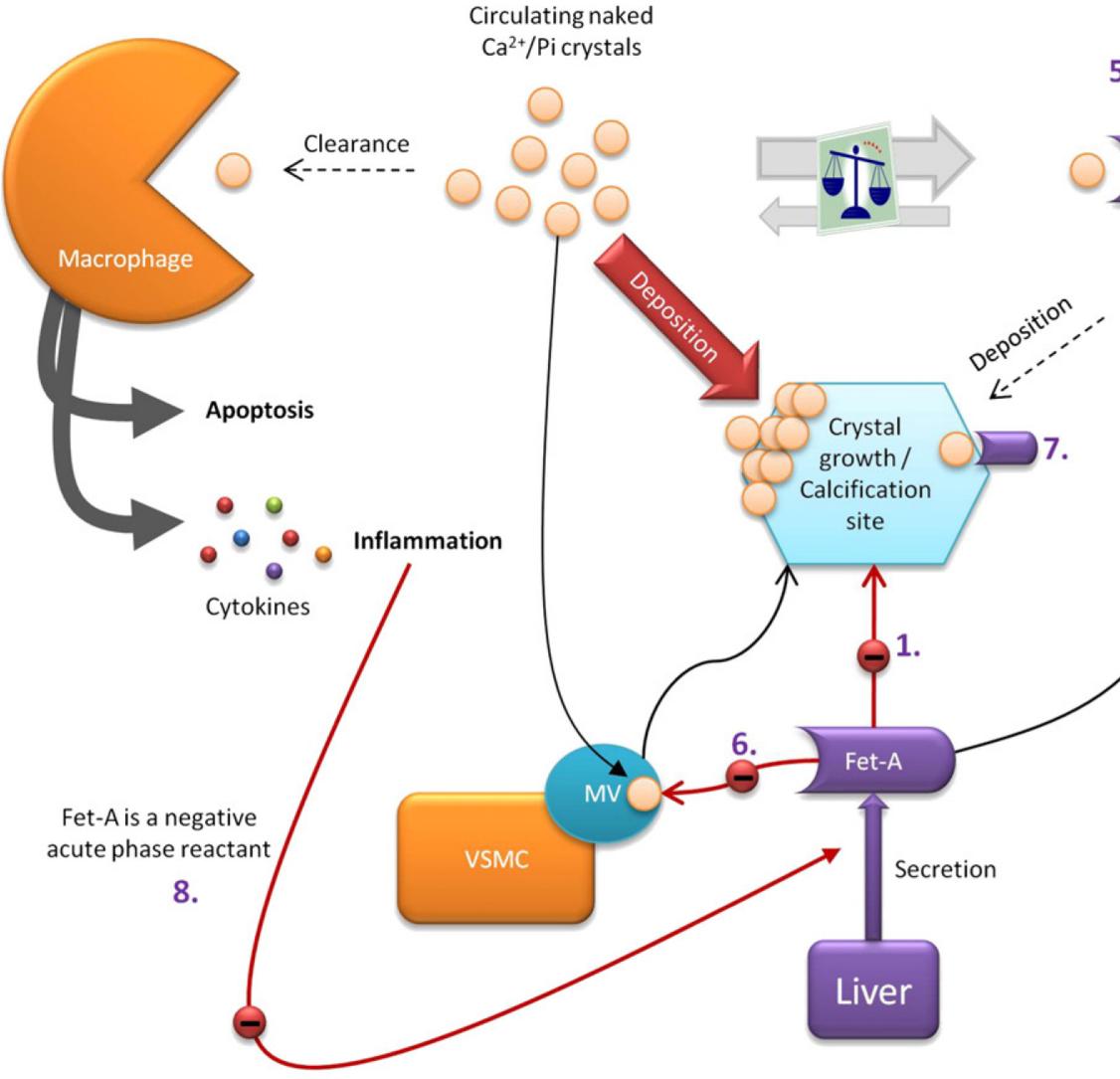

CPP = calciprotein particles. Fet $-\mathrm{A}=$ Fetuin $-\mathrm{A}$. VSMC $=$ Vascular smooth muscle cells MV = Matrix vesicles

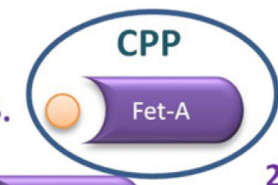

2.

Fet-A

Clearance

Fet-A
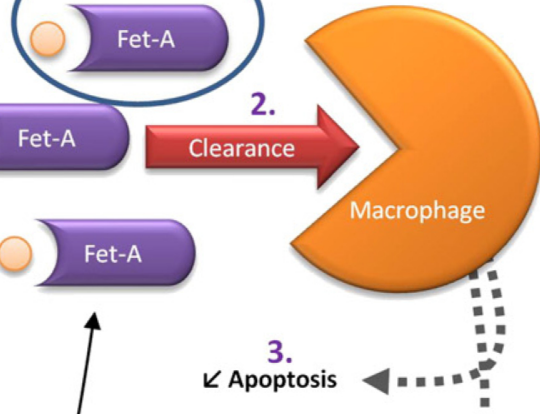

3.

$K$ Apoptosis

4.

$\swarrow$ Inflammation phosphate crytals.

2. CPP increase clearance of $\mathrm{Ca} 2+/ \mathrm{Pi}$ by macrophages.

3. CPP reduce macrophage apoptosis.

4. CPP reduce inflammation.

5. CPP fraction $\rightarrow$ better reflect of procalcific milieu ?

6. Fet-A $\measuredangle M V s$ mineralization.

7. Property to fixe crystal $\rightarrow$ accumulation at calcification sites and bones.

8. Fet-A concentration is decreased in dialysis patients, probably related to chronic inflammation, as Fet-A is a negative acute phase reactant.

Fig. 3. Properties of Fetuin-A.

Fet-A binds and sequesters insoluble mineral nuclei, forming soluble colloidal CPP, thereby inhibiting crystal growth and aggregation. Macrophages secrete less cytokines and undergo less apoptosis phenomenon compared to reactions caused by naked crystals. This property of Fet-A to decrease inflammation may be influenced by the phosphorylation degree of the glycoprotein [98]. The above mechanism partially explains the inhibitory effect of Fet-A in VC. Fet-A could also prohibit MV calcification into the VSMCs which take up circulating Fet-A from an extracellular calcium- dependent way $[99,100]$. Because its ability to bind calcium apatite crystals, Fet-A accumulates at sites of VC as well as in bone [101]. Increasing Fet-A expression is found in calcified arteries from dialysis patients [102].

Several studies support the evidence that lower serum levels of FetA levels might result in VC. In these studies, lower serum Fet-A concentrations have been associated with increases in calcification scores, arterial stiffness, mortality and incidence of cardiovascular events [83,103-106]. Among recent studies, Lee et al [83] found lower serum Fet-A in HD patients with valvular calcification. Abdel-Wahab et al. [103] showed significant negative correlation between Fet-A and indices of vascular disease in systemic lupus erythematosus patients. In a 277 renal transplant recipients followed-up during 5 years, Marechal et al. [106] showed that low Fet-A levels are independently associated with aortic - but not coronary - calcifications and a higher risk of cardiovascular events and mortality.

However, contradictory results have also been published regarding the role of Fet-A. After adjustment for age, in a 58 patients study of Jung et al. [107], an inverse correlation between Fet-A and coronary artery calcification score became insignificant. Low Fet-A was nonetheless associated with a significant increase in all-cause mortality and the occurrence of a cardiovascular event. Manghat et al. [108] did not find significant correlation between Fet-A and arterial stiffness in 45 predialysis patients. Hermans et al. [109] reported that, after correction for covariates, Fet-A could not be identified as an independent predictor of aortic stiffness in a dialysis population.

Interestingly, Hamono et al. [110] have suggested that estimates of the specific CPP fraction of total circulating fetuin may provide a better measure of extraskeletal mineral stress in patients with CKD. A recent study of Smith et al. [38] showed that increased CPP Fet-A levels reflect an increasingly procalcific milieu and are associated with increased aortic stiffness in patients with pre-dialysis CKD.

Despite the discrepancy between these various results, it should be noted that, in the majority of reports, low Fet-A serum levels are actually related with VC and increased mortality in patients with end stage renal disease. Nonetheless, the exact role of Fet- $\mathrm{A}$ in VC and cardiovascular diseases needs to be further evaluated through additional experimental and clinical studies [111].

\subsection{Matrix Gla protein (MGP)}

MGP is a vitamin K, 14-kDa $\gamma$-carboxylated protein expressed by chondrocytes, VSMCs, endothelial cells and fibroblasts. Its role as a calcification inhibitor has been illustrated by MGP knock-out mice who develop extensive arterial calcifications [112,113]. In 2002, Moe et al. demonstrated a correlation between vascular MGP expression and the calcification of epigastric arteries in dialysis patients [51,102]. MGP-deficiency in humans leads to Keutel syndrome, a rare genetic disease hallmarked by abnormal soft tissue calcification [113]. 
MGP binds calcium crystals, inhibits crystal growth and plays a role in the normal phenotype of VSMCs in preventing the osteoblastic differentiation [17,114]. MGP also binds and inactivates a pro-mineralization factor, bone morphogenetic protein-2 (BMP-2) [115]. Among other effects, BMP-2 promotes osteogenic conversion of VSMCs via MSX2 transcription factor. Nevertheless, BMP-2 inhibition may not play the leading role in MGP preventive action on calcification. Lomashvili et al. [116] used warfarin as MGP inhibitor in cultured aortas but did not observe a decrease in calcification by adding BMP-2 antagonist. In this study, the lack of involvement of BMP-2 supports the possibility that MGP prevents medial calcification by directly binding hydroxyapatite and inhibiting its formation, which is consistent with the fact that the content of MGP in calcified aortas is proportional to hydroxyapatite content. MGP could also play a role in Fet-A calciprotein complexes. Recently, Khavandgar et al. [113] hypothesized that deleterious effect of MGP deficiency could be linked to an extracellular matrix alteration. Indeed, in their study on MGP knock-out mice, they found that VSMCs differentiation did not precede the calcification phenomenon while MGP $-/-$ aortas showed altered extracellular matrix remodeling. Furthermore, they showed that elastin haploin sufficiency reduced arterial calcification in MGP $-/-$ elastin $+/-$ mice. Elastin is a major elastic lamina protein and has been shown to act as a mineral nucleator. MGP could protect mineral nucleation sites on elastin and thereby prevent spontaneous calcification of the elastic laminae. In support of that, the irregular calcification of the thoracic and abdominal aorta segments in MGP - / - mice correlates with the local variations of the elastin content [113]. Parallel to this study, other authors hypothesized a mineralization process by size exclusion, in which MGP proves to be essential to prevent mineralization within fibrils. Indeed, most inhibitors are bigger than MGP and cannot access nucleation sites located on fibrils, generating mineralization in the absence of MGP $[117,118]$.

MGP may undergo two post-translational modifications : glutamate carboxylation and serine phosphorylation. It thus exists in four different forms. Whereas the accurate role of phosphorylation is not fully elucidated, it is well established that carboxylation is needed for MGP activity. Balance between carboxylated (c) MGP and uncarboxylated (uc) MGP is thereby very important [117]. Using conformation specific antibodies, it has been reported that uc MGP is significantly present in the calcified vasculature whereas c MGP is nearly absent. It has been shown that non fully $\gamma$-carboxylated (but not $\gamma$-carboxylated MGP) is associated with VC $[5,119,120]$. However, total uc MGP seems to be inversely correlated with VC [121]. As total uc MGP includes phosphorylated and non-phosphorylated fractions and given the fact that phosphorylation may be involved in MGP activity, it is important to selectively dose the dephosphorylated-uncarboxylated (dp-uc) MGP inactive fraction. In a multivariate linear regression analysis, Schurgers et al. [122] have evidenced an independent association between plasma dp-uc MGP levels and aortic calcification whereas Schlieper et al. [123] did not find any correlation with the extent of VC. The discrepancy between these results could perhaps be explained by the use of different assays, as there is no validated analytic process yet.

Activation of MGP by $\gamma$-carboxylation is vitamin $\mathrm{K}$ dependant $[5,20,112,120]$. In the case of vitamin K deficiency, VC phenomenon can therefore be magnified. Treatment with Vitamin K antagonists (AVK) also lead to the same consequence [117].This is the actual explanation for the observations that warfarin leads to extensive VCs in animal and human studies [124-126]. It is interesting to note that vitamin K therapy partially reverses warfarin-induced VCs in rats [126]. As AVK are the most prescribed anticoagulant medication to date, it is necessary to establish whether the benefit outweighs the long-term risk to develop increased VC, especially in diabetic or CKD patients [117].

3.4. Bone Morphogenetic Protein - 2 (BMP-2)

Bone morphogenetic proteins (BMPs) belong to a subdivision of TGF- $\beta$ like growth factors family. BMPs regulate growth, differentiation and development in the embryo as well as during tissue remodeling processes in the adult organism. BMP-2 is an important molecule in the regulation of bone formation as well as in VC. In bone, it promotes osteoblast differentiation and mineralization [127]. Inhibition of BMP2 inhibits osteoblast differentiation and bone formation in vivo and in vitro [128] and protects against atherosclerosis and VC [129]. BMP2 was detected in calcified human VSMCs by mRNA levels and by immunohistochemistry. The change in gene expression of these cells might be considerably regulated by BMP-2. It appears that a novel mechanism of BMP-2 activation would have been discovered recently. A protease from the coagulation called factor VII-activating protease (FSAP) would mediate BMP-2 cleavage and generation of truncated BMP-2, which is characterized by enhanced activity [130].

Ligand-bound receptor signaling results in smad $1 / 5 / 8$ phosphorylation. The phosphorylated smads are then able to enter nucleus and lead to transcriptional modification [130]. BMP-2 would also be involved in microRNA-30b and microRNA-30c decreasing, likely through a smadindependent pathway. MicroRNAs are small noncoding RNAs which link specific complementary mRNA sequences. This binding drives to translation inhibition and promotes mRNA degradation, so that this one cannot produce protein anymore. MicroRNA-30b and microRNA$30 \mathrm{c}$ are plausible candidates to regulate runx2 expression. Runx2 is an important factor in VSMCs transition into osteoblast-like cells. Thus, BMP-2 would perhaps promote VSMCs calcification by increasing runx2 expression through microRNA-30b and microRNA-30c downregulation [131].

\subsection{Osteoprotegerin (O) and RANKL/Rank axis}

OPG is a regulatory factor produced by bone marrow derived stromal cells. OPG plays a pivotal role in the regulation of the bone turnover, inhibiting osteoclast differentiation and acting like a decoy receptor for the receptor activator of NF-KB ligand (RANKL system) [132]. It interferes with the interaction between RANK (expressed by osteoclast-like cells) and RANKL (expressed by osteoblast-like cells). OPG is also thought to inhibit ALP activity [133]. OPG levels are significantly higher in CKD patients, in relation with the severity of renal failure. Although OPG is known to impede osteoclast differentiation in bone, OPG is usually considered as a protective factor against VC as it blocks the bone remodeling process in the vascular tissue whereas RANKL is thought to have a negative action. OPG is also a neutralizer of the proapoptotic actions of TRAIL (TNF-related apoptosis-inducing ligand), which strongly activates vascular cells apoptosis [134]. Apoptotic bodies can also lead to mineralization. In support of that, it has been observed that OPG deficient mice do develop both severe aortic calcifications and osteoporosis [135] and that calcified arteries are known to have higher levels of RANKL expression and lower levels of OPG [136]. Zhou et al. [137] isolated VSMCs from thoracic aorta of rats and cultured them in osteogenic medium. They found osteoblastic differentiation was markedly reduced by addition of OPG in a dose responsive way. They noticed that this addition also lead to decrease in Notch1 and RBP-Jk mRNA, which are upstream contributors of the Msx2 pathway, known as an osteoblastic conversion path.

However, other findings suggest a more complex picture. Morena et al.[138] found a strong relationship between OPG high plasma levels and CAC in CKD patients. In this study, the cut-off value best predicting CAC score was $757.7 \mathrm{pg} / \mathrm{ml}$ (sensitivity $=91.7 \%$; specificity $=59.0 \%$ ). To improve diagnostic performance, two threshold values have been proposed : the lower one below which CAC is excluded $(<709.9 \mathrm{pg} / \mathrm{ml})$ and the highest one above which CAC is accepted $(>963.7 \mathrm{pg} / \mathrm{ml}$ ) with a grey area within which the diagnostic remains uncertain. This compromise resulted in a reduced $12.8 \%$ error rate. It is important to consider that these values were established in CKD patients before dialysis initiation. Indeed, OPG is not removed correctly by HD and therefore accumulates. Interestingly, OPG seems to be a marker of VC onset rather than a severity or progression predictor. This was an 
observation of a study which investigated the relation between OPG, FGF-23 and CAC in a ND-CKD population [85]. Despite the fact that OPG levels were significantly increased in patients with moderate vs. mild CAC, an additional increase of OPG levels in patients with severe calcification was not observed. In contrast, FGF-23 better reflected severe calcifications vs. milder ones. Many other trials have also shown that VC as well as arterial stiffness and cardiovascular events are inversely related to serum RANKL [139-141] and positively related to serum OPG $[83,136,138,139,141-149]$. Although some convincing assumptions are proposed to explain why OPG levels correlate with calcification, it has still to be decided whether OPG is rather a marker, a protector or an active player in calcification process.

Position of RANKL in the physiopathology is not perfectly clear either. Some in vitro studies have showed that RANKL treatment induces VC, whereas others found no effect, albeit in different species and culture conditions [136]. Many studies used transfected RANKL mice models to assess impact of RANKL overexpression on vascular system. The overexpression was global or the distribution was systemic (released from the liver for example). These methods do not permit to distinguish RANKL direct effects on the vasculature from indirect effects induced by bone remodeling. So Morony et al. [136] have recently conceived a transfected mice model in which RANKL was solely expressed in VSMCs. To do so, they linked RANKL gene to a promoter whose expression was highly restricted to VSMCs in adult tissues. No calcium deposition in the aortic roots has been revealed. Although SM22 $\alpha$-Rankl ${ }^{\text {tg }}$ mice do not develop spontaneous VC, it is possible that these mice develop greater $\mathrm{VC}$ than normal mice when exposed to procalcific factors. The team has not been able to demonstrate an increase in calcification with cultured SM22 $\alpha$-Rank ${ }^{\text {tg }}$ cells either. Furthermore, Olesen et al. [150] studied the effect of RANKL recombinant treatment on human OPG knockdown VSMCs and they did not find any modification in calcification-associated genes expression pattern. Nonetheless, a different approach has been tempted by Deuell et al. [151]. As macrophages are able to induce apoptosis and differentiation of VSMCs through an inflammatory process, the hypothesis that RANKL regulates VSMCs calcification by modulating macrophage production of pro-calcific cytokines was tested. In order to explore this, they used a bone marrow-derived macrophage (BMDM)/VSMCs co-culture system. Treatment of BMDMs with RANKL resulted in expression of IL- 6 and TNF- $\alpha$. According to this team, increased expression of these pro-calcific cytokines in macrophages might then mediate RANKL-induced VSMCs calcification in a paracrine way.

Those are the reasons why it is difficult to establish the accurate role of OPG-RANK/RANKL axis. High serum levels of OPG are associated with greater calcification, but this may be a reflection of a noxious OPG activity on the vasculature or it also could be the witness of a compensatory mechanism setting. Indeed, OPG levels could rise in response to a vascular injury and would then attempt to control, in part, vascular remodeling. This hypothesis is supported by OPG-/- animal experiences in which they developed severe calcifications, unless calcification has been an indirect repercussion of an excessive bone resorption. Some publications have shown a decrease or even an inhibition in VC, using recombinant OPG treatment or denosumab (a RANKL inhibitor) in mice [152,153], but not in clinical study with post menopausal women [154]. As OPG can be secreted by VSMCs which underwent osteoblastic differentiation, OPG could merely be a bystander too.

\subsection{Osteopontin (OPN)}

OPN is a phosphoprotein expressed in the mineral tissues which inhibits mineralization by blocking hydroxyapatite formation and activating osteoclast function [155]. OPN is present in calcified vessels. OPN knock-out mice do not develop VC but, when these mice are bred with MGP knock-out mice, the VCs are more important than in simple MGP knock-out mice [156]. OPN must be phosphorylated to act as a calcification inhibitor [157]. OPN inhibits mineralization of VSMC by binding to the mineralized crystal surface [158]. On the contrary to the fully phosphorylated OPN, cleaved OPN could act as a proinflammatory cytokine and a proangiogenic factor facilitating vascular mineralization $[155,159]$.

The possibility that OPN could serve as a calcification serum marker is controversial. Berezin et al. [160] showed that OPN was a good predictor of coronary calcification in type two diabetes mellitus patients. Tousilis et al. [149] found a positive association between OPN and arterial stiffness in coronary artery disease. However, all trials do not come to the same conclusions: although OPN serum levels were considerably increased in patients with abdominal aortic aneurysms, no independent correlation between arterial stiffness (assessed by pulse wave velocity) and OPN could be highlighted after multiple regression analysis [161]. Albu et al. [142] did not find any correlation between OPN levels and arterial stiffness in postmenopausal women. However, it is interesting to notice that OPN correlated positively with hsCRP and negatively with HDL-C. Indeed, the discrepancy between the different studies may perhaps be explained by the differences in patient populations. It is thought OPN plays a key role in inflammatory process. Its relation with diseases related to inflammation such as atherosclerosis, obesity and auto-immune diseases has already been shown [142,155,162-164]. It has also been suggested that hyperglycemia could up-regulate OPN and thereby lead to VSMCs proliferation [165].

\subsection{Osteonectin (On)}

ON, also called SPARC or BM40, is a calcium binding protein involved in bone development that demonstrates affinity for hydroxyapatite and collagen [166]. ON has been found in association with large calcifications in atherosclerotic plaques [167]. The lack of knowledge on osteonectin doesn't allow to define its specific role. Further investigations are needed to precise its utility in calcification assessment.

\subsection{Osteocalcin (Oc)}

OC, a vitamin-K dependent matrix protein that inhibits calcium salt precipitation in vitro [168], shows a strong affinity for hydroxyapatite. OC has been found in calcified atherosclerotic plaques and calcified aortic valves [169]. It was generally thought that OC inhibits crystal growth [170] and limits bone formation [171], but different studies challenge this point of view and suggest the opposite idea [172,173]. Hence, a metabolic role for OC has newly been suggested. As OC has been shown to stimulate insulin secretion by pancreas and glucose uptake in adipose tissue, Ideleviech et al. [174] wanted to consider direct metabolic effects of OC on VSMCs and chondrocyte cells with an in vitro OC overexpression model. They found that $\mathrm{OC}$ functions as a stimulator of differentiation and mineralization, up-regulating Sox9, Runx2, collagen type X, ALP, proteoglycans, and mineral content in both of these cells. In particular, OC increases hypoxia-inductible factor $1 \alpha$ (HIF-1 $\alpha)$ activation, which promotes glucose uptake and modulate its metabolism. HIF- $1 \alpha$ is hydroxylated under normal conditions but in hypoxic situations, hydroxylation of HIF-1 $\alpha$ does not occur and $\alpha$ subunit translocates to the nucleus to bind $\beta$ counterpart. The heterodimer triggers a modification of genes expression. These genes are involved, among other effects, in glucose metabolism. This mechanism is likely used in bone tissue as an adaptive way to poorly vascularized and hypoxic environment. The group also showed that OC siRNA silencing counteracts $1,25(\mathrm{OH})_{2} \mathrm{D}$ induced model of $\mathrm{VC}$ in young rats [174]. In an interesting way, Flammer et al. [175] selected CD133 +/CD34-/KDR + endothelial progenitor cells (EPCs) and demonstrated that expression of $\mathrm{OC}$ on circulating early EPCs is strongly associated with unstable coronary artery disease. Fadini et al. [176] also showed a procalcific polarization of circulating progenitor cells in type 2 diabetes mellitus patients, especially those who suffer from coronary artery disease.

OC levels are known to increase in HD patients $[177,178]$. OC regulation clearly undergoes disruption during mineralization process. 
Nonetheless, its utility as serum marker is still discussed in conflicting studies. Aoki et al. [148] did not show any relationship between OC and VC in type 2 diabetes mellitus patients whereas Kim et al. [179] found an inverse correlation between OC and Agatston calcification score in Asian women, even after adjusting for age. In order to define if OC can be used as a diagnostic or a screening tool, the role of OC in the pathogenesis of VC clearly remains to be clarified.

\subsection{Pyrophosphate (Ppi)}

PPi is a small molecule made of two phosphate ions. It acts as a calcification inhibitor by inhibiting hydroxyapatite crystal formation [180]. Once again, knock-out mice (in fact, knock-out mice for a precursor) develop VCs [181]. Absence of PPi would promote VSMC differentiation but the mechanism is not fully understood [182,183]. Absence of PPi combined with high phosphate levels and presence of type 1 collagen could facilitate the development of calcification [184,185]. Two ectonucleotidases have been implicated in extracellular PPi (ePPi) homeostasis during VSMCs calcification: tissue-non specific ALP hydrolyzes ePPi to phosphate, and nucleotide pyrophosphatase/ phosphodiesterase-1 (eNPP1) generates ePPi by extracellular ATP hydrolysis [186].

It has been shown that dialysis patients exhibit low serum PPi and that these are further lowered during a HD session. PPi plasma levels were not affected by the mode of dialysis or by nutritional or inflammatory status [187]. O'Neill et al. [188] demonstrated the negative association between PPi and VC in CKD.

Although the short half life of PPi limits the possibility for improving VC by bolus injections, daily peritoneal dialysis achieved with a solution which contains PPi in CKD mouse model do succeed in inhibiting calcification [189]. O'Neill et al [190] demonstrated that daily intraperitoneal injections in rats could also reduce both incidence and amount of calcification. PPi has been shown to inhibit mineralization on rat aortic VSMCs cultures too [191]. Furthermore, biphosphonates, non hydrolysable analogs of PPi, have also proved their ability to inhibit aortic calcifications in experimental renal failure rats. Calcification was stopped in cultures of rat aortas as well as in vivo model. It supports the idea that biphosphonates have direct effects on VC, independent of bone [192], maybe via a down regulation of Notch1-RBP-Jk signaling pathway and MsX2 gene induction [193]. ATP, which is a polyphosphate associated with nucleoside, might also act as calcium phosphate deposition inhibitor, not only as the source of PPi but also as a direct inhibitor [186]. Even if PPi seems to be a promising marker, its determination has been performed in a single center only and the transferability to other centers should be validated.

\subsection{Sclerostin}

Sclerostin is an osteocyte-specific glycoprotein and is considered as a potent inhibitor of bone formation $[194,195]$. It inhibits specific coreceptors needed for $\beta$-catenin-dependant signaling activation [196]. This pathway is involved in osteoblast-mediated bone formation [197] .It is thought that sclerostin plays a role in bone mechanosensibilisation. When bone undergoes a substantial strain, sclerostin production would be decreased and bone could thus increase its formation in response to mechanical stress [198]. As $\beta$-catenin belongs to Wnt cascade signaling and as Wnt pathway is thought to be implicated in development of VC, it is interesting to investigate a potential association between sclerostin levels and VCs. In non-CKD patients, some studies have demonstrated a positive association between sclerostin levels and VC [199,200] whereas in other ones, there was not a significant correlation between the two parameters [201,202]. Results of similar investigations seem quite different in specific population of HD patients. Indeed, in their study including 154 CKD patients, Claes et al. [203] highlighted absence of calcifications as an independent predictor of higher level of sclerostin. Further studies are needed for confirming a possible sclerostin involvement in VC genesis and for defining its potential usefulness in VC assessment.

\section{Discussion}

Today, the ideal marker of VC does not exist. The pathophysiological mechanisms underlying this phenomenon are still poorly understood. As explained in the introduction, calcification can be induced by various situations. Etiologies that induce VC in diabetes mellitus patients are likely different from those which lead to the same result in CKD patients or postmenopausal women. Signaling pathways that are involved in VC may then depend on patient's status. A perfect marker would be ideally located on a hypothetical convergence point of all these pathological conditions. Thus, it could reflect reliably calcification emergence and progression in any situation. But this view is maybe too utopian and simplistic. Over the years, study of biomarkers showed a large variety of conditions that can modulate vascular microenvironment composition, such as bone turnover, inflammation, vitamin D status or even oxidative stress. Within this vascular microenvironment itself, a dense and interconnected network of calcification inhibitors and promoters was highlighted, as shown by Fig. 4 .

(1) VSMCs undergo differentiation into osteoblast-like cells, in great part because of an intracellular phosphate increased concentration, likely mediated by the co-transporter Pit-1, in response to extracellular hyperphosphatemia. (2) Renal failure is one of the major hyperphospatemia origin whereas (3) FGF-23 is a factor which tend to moderate it by increasing phosphate renal excretion. This FGF-23 action is achieved with Klotho's help. FGF-23 has other effects described in Fig. 2, among which noxious ones are also suspected. (4) Other factors such as BMP-2, absence of PPi (in part, due to ALP activity), oxidative stress, inflammatory process or metabolic disorders are also known to be responsive to VSMCs conversion. (5) Calcium enhancement also proved to be deleterious, especially by its ability to induce Pit-1 overexpression and also by alteration of MGP and Fetuin-A actions, two VC inhibitors.

(6) The VSMCs conversion will favor excretion of bone-associated proteins, such as OPN, collagen type 1, BMP-2 and OC and (7) VSMCs will release mineralization-competent MVs. In turn, (8) BMP-2 can promote osteoblast differentiation and is a potent calcification inducer. (9) MGP, expressed by chondrocytes and VSMCs under normal conditions, inactivates BMP-2. It also binds calcium crystals and inhibits crystal growth. Finally, it prevents osteoblastic differentiation too. As osteocalcin, its activity is vitamin-K dependent and can be countered by vitamin-K antagonists.

(10) Osteocalcin and (11) osteonectin are known to bind $\mathrm{Ca} / \mathrm{Pi}$ crystal but their accurate actions as inducers or inhibitors need to be specified, whereas the (12) PPi inhibiting effect on crystal formation is well known. The recent discovery of OC metabolic effects might suggest $\mathrm{OC}$ is a promoter of VSMCs differentiation into osteoblast-like cells. (13) OPN activity would depend on its phosphorylation state. Fully phosphorylated OPN would inhibit mineralization by blocking hydroxyapatite formation and activating osteoclast function while the cleaved one could act as a proinflammatory cytokine and proangiogenic factor facilitating vascular mineralization.

(14) OPG is considered as a regulatory factor. On one hand, it can prevent VC by blocking bone remodeling process in vascular tissue and by neutralizing the pro-apoptotic actions of TRAIL. It might also inhibit ALP activity. On the other hand, the inhibition of bone remodeling process by OPG could induce a calcium shift into vascular cells. (15) FetA released by the liver inhibits mineralization, perhaps through calciprotein particles formation while (16) PTH secreted by parathyroid enhances calcification phenomenon, as both low and high bone turnover might lead to VC.

Under normal conditions, there is a balance between all these parameters. It is possible that each pathological condition disrupts the balance with its own approach. Nevertheless, it seems that all the 


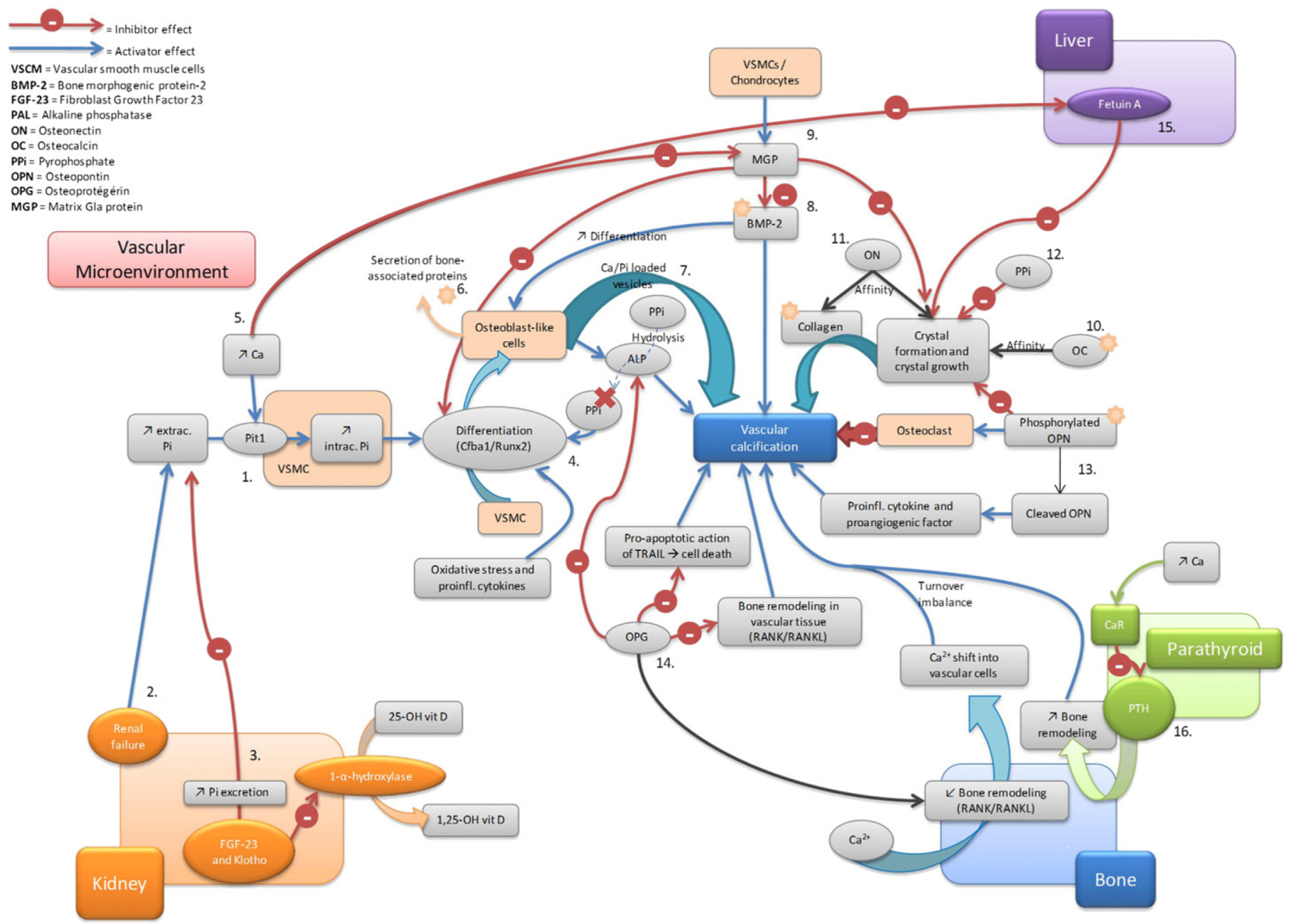

Fig. 4. Vascular microenvironment: inhibitors and promoters of vascular calcification.

calcification inhibitors do not possess the same potential. OPG serum levels appear to be correlated repeatedly to calcification in many pathological conditions. However, OPG would not reflect the severity of damages as would FGF-23 do. FGF-23 levels should be followed up, either upwards or downwards, given the suspected duality of the effects of FGF-23. Low serum Fet-A levels are usually associated with VC but an increased CPP fraction of Fet-A would also be useful to reflect a procalcific milieu. Non fully $\gamma$-carboxylated MGP is associated with VC too and might be an interesting marker to monitor patients under AVK treatment. OPN would be an attractive marker in diseases with inflammatory component such as diabetes or autoimmune diseases. Within this category of disease, it might help to reclassify asymptomatic subjects with classical risk factors into high risk group for further examination.

In population with renal deficiency particularly susceptible to develop VC, the problem becomes even more complex. Whether patients undergo dialysis or not, reference values will need to be adaptated, depending on renal failure severity and marker ability to be removed by dialysis. In addition, as described earlier, complex interactions exist between different actors (pro or anti-calcifications) such as PTH, vitamin D, FGF-23, OPG, Sclerostin, acting sometimes via redundant signaling pathways such as Wnt/ß-catenin, RunX2/cbfa1, Notch1-RBP-Jk. Furthermore, these interactions could be different according to the stage of CKD [204]. Thus, the stage of disease should be taken into account in the interpretation of biomarker and/or the combination of biomarkers.

As evidenced by the present discussion, VC physiopathology is still far from being fully elucidated. The role of each biomarker needs to be clarified and many studies are still leading to contradictory results. In vitro observations are sometimes very different from conclusions observed in in vivo studies. Direct effects on vasculature and indirect effects mediated by bone turnover are not easy to discriminate. When a correlation between the serum levels of a calcification marker and calcification is clearly showing up, it still remains to determinate whether level fluctuations attest a noxious effect of the biomarker or if they highlight a compensatory process or even solely reflect phenomenon as bystander.

Qualities that would be appreciated for selecting a good marker depend on its capacities to achieve clinical goals, particularly its ability to select high risk patients for further investigation, to make a reliable calcification assessment, to provide a prognostic, to help in treatment choice or to follow up the treatment efficiency. Given importance to assess and control mineralization process, it is essential to keep going on building-up more and more knowledge.

\section{References}

[1] Murphy Jr WA, Nedden Dz D, Gostner P, Knapp R, Recheis W, Seidler H. The iceman: discovery and imaging. Radiology 2003;226:614-29.

[2] Virchow R. Arch Pathol Anat 1855;8:103-13.

[3] Hofmann Bowman MA, McNally EM. Genetic pathways of vascular calcification. Trends Cardiovasc Med 2012;22:93-8.

[4] Kapustin AN, Davies JD, Reynolds JL, et al. Calcium regulates key components of vascular smooth muscle cell-derived matrix vesicles to enhance mineralization. Circ Res 2011;109:e1-12.

[5] Giachelli CM. Vascular calcification mechanisms. J Am Soc Nephrol 2004;15: 2959-64. 
[6] Rutsch F, Nitschke Y, Terkeltaub R. Genetics in arterial calcification: pieces of a puzzle and cogs in a wheel. Circ Res 2011;109:578-92.

[7] Assimes TL, Knowles JW, Basu A, et al. Susceptibility locus for clinical and subclinical coronary artery disease at chromosome 9p21 in the multi-ethnic ADVANCE study. Hum Mol Genet 2008;17:2320-8.

8] Lange LA, Lange EM, Bielak LF, et al. Autosomal genome-wide scan for coronary artery calcification loci in sibships at high risk for hypertension. Arterioscler Thromb Vasc Biol 2002;22:418-23.

[9] O'Donnell CJ, Kavousi M, Smith AV, et al. Genome-wide association study for coronary artery calcification with follow-up in myocardial infarction. Circulation 2011; 124:2855-64

[10] Myocardial Infarction Genetics Consortium, Kathiresan S, Voight BF, et al. Genomewide association of early-onset myocardial infarction with single nucleotide polymorphisms and copy number variants. Nat Genet 2009;41:334-41.

[11] Li Q Jiang Q Schurgers LJ, Uitto J. Pseudoxanthoma elasticum: reduced gammaglutamyl carboxylation of matrix gla protein in a mouse model (Abcc6-/-). Biochem Biophys Res Commun 2007;364:208-13.

[12] Moe SM, Duan D, Doehle BP, O'Neill KD, Chen NX. Uremia induces the osteoblast differentiation factor Cbfa1 in human blood vessels. Kidney Int 2003;63:1003-11.

[13] Giachelli CM. Vascular calcification: in vitro evidence for the role of inorganic phosphate. J Am Soc Nephrol 2003;14:S300-4.

[14] Jono S, McKee MD, Murry CE, et al. Phosphate regulation of vascular smooth muscle cell calcification. Circ Res 2000;87:E10-7.

[15] Li X, Yang HY, Giachelli CM. Role of the sodium-dependent phosphate cotransporter, Pit-1, in vascular smooth muscle cell calcification. Circ Res 2006; 98:905-12.

[16] Steitz SA, Speer MY, Curinga G, et al. Smooth muscle cell phenotypic transition associated with calcification: upregulation of $\mathrm{Cbfa} 1$ and downregulation of smooth muscle lineage markers. Circ Res 2001;89:1147-54.

[17] Mizobuchi M, Towler D, Slatopolsky E. Vascular calcification: the killer of patients with chronic kidney disease. J Am Soc Nephrol 2009;20:1453-64.

[18] Giachelli CM, Bae N, Almeida M, Denhardt DT, Alpers CE, Schwartz SM. Osteopontin is elevated during neointima formation in rat arteries and is a novel component of human atherosclerotic plaques. J Clin Invest 1993;92:1686-96.

19] Levy RJ, Schoen FJ, Levy JT, Nelson AC, Howard SL, Oshry LJ. Biologic determinants of dystrophic calcification and osteocalcin deposition in glutaraldehyde-preserved porcine aortic valve leaflets implanted subcutaneously in rats. Am J Pathol 1983; 113:143-55.

[20] Reynolds JL, Joannides AJ, Skepper JN, et al. Human vascular smooth muscle cells undergo vesicle-mediated calcification in response to changes in extracellular calcium and phosphate concentrations: a potential mechanism for accelerated vascular calcification in ESRD. J Am Soc Nephrol 2004;15:2857-67.

[21] Kapustin AN, Shanahan CM. Calcium regulation of vascular smooth muscle cellderived matrix vesicles. Trends Cardiovasc Med 2012;22:133-7.

[22] Kendrick J, Chonchol M. The role of phosphorus in the development and progression of vascular calcification. Am J Kidney Dis 2011;58:826-34

[23] Giachelli CM, Speer MY, Li X, Rajachar RM, Yang H. Regulation of vascular calcification: roles of phosphate and osteopontin. Circ Res 2005;96:717-22.

[24] Kim KM. Apoptosis and calcification. Scanning Microsc 1995;9:1137-75 [discussion 1175-1138].

[25] Kockx MM, De Meyer GR, Muhring J, Jacob W, Bult H, Herman AG. Apoptosis and related proteins in different stages of human atherosclerotic plaques. Circulation 1998:97:2307-15.

[26] Proudfoot D, Skepper JN, Hegyi L, Bennett MR, Shanahan CM, Weissberg PL. Apoptosis regulates human vascular calcification in vitro: evidence for initiation of vascular calcification by apoptotic bodies. Circ Res 2000;87:1055-62.

[27] Pal SN, Golledge J. Osteo-progenitors in vascular calcification: a circulating cell theory. J Atheroscler Thromb 2011;18:551-9.

[28] Tang Z, Wang A, Yuan F, et al. Differentiation of multipotent vascular stem cells contributes to vascular diseases. Nat Commun 2012;3:875

[29] Shanahan CM, Crouthamel MH, Kapustin A, Giachelli CM. Arterial calcification in chronic kidney disease: key roles for calcium and phosphate. Circ Res 2011;109: 697-711.

[30] Sutra T, Morena M, Bargnoux AS, Caporiccio B, Canaud B, Cristol JP. Superoxide production: a procalcifying cell signalling event in osteoblastic differentiation of vascular smooth muscle cells exposed to calcification media. Free Radic Res 2008:42:789-97.

[31] Byon $\mathrm{CH}$, Javed $\mathrm{A}$, Dai $\mathrm{Q}$, et al. Oxidative stress induces vascular calcification through modulation of the osteogenic transcription factor Runx2 by AKT signaling. J Biol Chem 2008;283:15319-27.

[32] Shao JS, Cheng SL, Pingsterhaus JM, Charlton-Kachigian N, Loewy AP, Towler DA. Msx2 promotes cardiovascular calcification by activating paracrine Wnt signals. J Clin Invest 2005;115:1210-20.

[33] Lee HL, Woo KM, Ryoo HM, Baek JH. Tumor necrosis factor-alpha increases alkaline phosphatase expression in vascular smooth muscle cells via MSX2 induction. Biochem Biophys Res Commun 2010;391:1087-92.

[34] Tintut Y, Patel J, Parhami F, Demer LL. Tumor necrosis factor-alpha promotes in vitro calcification of vascular cells via the cAMP pathway. Circulation 2000; 102:2636-42.

[35] Tintut Y, Patel J, Territo M, Saini T, Parhami F, Demer LL. Monocyte/macrophage regulation of vascular calcification in vitro. Circulation 2002;105:650-5.

[36] Aikawa E, Nahrendorf M, Figueiredo JL, et al. Osteogenesis associates with inflammation in early-stage atherosclerosis evaluated by molecular imaging in vivo. Circulation 2007;116:2841-50.

[37] Shanahan CM. Inflammation ushers in calcification: a cycle of damage and protection? Circulation 2007;116:2782-5.
[38] Smith ER, Ford ML, Tomlinson LA, Rajkumar C, McMahon LP, Holt SG. Phosphorylated fetuin-A-containing calciprotein particles are associated with aortic stiffness and a procalcific milieu in patients with pre-dialysis CKD. Nephrol Dial Transplant 2012;27:1957-66

[39] Menini S, lacobini C, Ricci C, et al. The galectin-3/RAGE dyad modulates vascular osteogenesis in atherosclerosis. Cardiovasc Res 2013;100:472-80.

[40] Averill MM, Kerkhoff C, Bornfeldt KE. S100A8 and S100A9 in cardiovascular biology and disease. Arterioscler Thromb Vasc Biol 2012;32:223-9.

[41] Hofmann Bowman MA, Schmidt AM. S100/calgranulins EN-RAGEing the blood vessels: implications for inflammatory responses and atherosclerosis. Am J Cardiovasc Dis 2011;1:92-100.

[42] Caudrillier A, Mentaverri R, Brazier M, Kamel S, Massy ZA. Calcium-sensing receptor as a potential modulator of vascular calcification in chronic kidney disease. J Nephrol 2010;23:17-22.

[43] Alam MU, Kirton JP, Wilkinson FL, et al. Calcification is associated with loss of functional calcium-sensing receptor in vascular smooth muscle cells. Cardiovasc Res 2009;81:260-8.

[44] Ivanovski O, Nikolov IG, Joki N, et al. The calcimimetic R-568 retards uremiaenhanced vascular calcification and atherosclerosis in apolipoprotein $\mathrm{E}$ deficient (apoE-/-) mice. Atherosclerosis 2009;205:55-62.

[45] Henaut L, Boudot C, Massy ZA, et al. Calcimimetics increase CaSR expression and reduce mineralization in vascular smooth muscle cells: mechanisms of action. Cardiovasc Res 2014;101:256-65.

[46] Parhami F, Tintut Y, Ballard A, Fogelman AM, Demer LL. Leptin enhances the calcification of vascular cells: artery wall as a target of leptin. Circ Res 2001;88: 954-60.

[47] Zeadin M, Butcher M, Werstuck G, Khan M, Yee CK, Shaughnessy SG. Effect of leptin on vascular calcification in apolipoprotein E-deficient mice. Arterioscler Thromb Vasc Biol 2009;29:2069-75.

[48] Hill JA, Olson EN, Griendling KK, Kitsis RN, Stull JT. Muscle: fundamental biology and mechanisms of disease. Elsevier Science \& Technology Books; 2012.

[49] Doherty TM, Uzui H, Fitzpatrick LA, et al. Rationale for the role of osteoclast-like cells in arterial calcification. FASEB J 2002;16:577-82.

[50] Mozar A, Haren N, Chasseraud M, et al. High extracellular inorganic phosphate concentration inhibits RANK-RANKL signaling in osteoclast-like cells. J Cell Physiol 2008;215:47-54.

[51] Moe SM, O'Neill KD, Duan D, et al. Medial artery calcification in ESRD patients is associated with deposition of bone matrix proteins. Kidney Int 2002;61:638-47.

[52] Ketteler M, Biggar PH. Review article: Getting the balance right: assessing causes and extent of vascular calcification in chronic kidney disease. Nephrology 2009; $14: 389-94$.

[53] Goldsmith D, Ritz E, Covic A. Vascular calcification: a stiff challenge for the nephrologist: does preventing bone disease cause arterial disease? Kidney Int 2004;66: 1315-33.

[54] Braun J, Oldendorf M, Moshage W, Heidler R, Zeitler E, Luft FC. Electron beam computed tomography in the evaluation of cardiac calcification in chronic dialysis patients. Am J Kidney Dis 1996;27:394-401.

[55] London GM, Marty C, Marchais SJ, Guerin AP, Metivier F, de Vernejoul MC. Arterial calcifications and bone histomorphometry in end-stage renal disease. J Am Soc Nephrol 2004;15:1943-51.

[56] London GM, Marchais SJ, Guerin AP, Boutouyrie P, Metivier F, de Vernejoul MC. Association of bone activity, calcium load, aortic stiffness, and calcifications in ESRD. J Am Soc Nephrol 2008;19:1827-35.

[57] Barreto DV, Barreto FC, Carvalho AB, et al. Coronary calcification in hemodialysis patients: the contribution of traditional and uremia-related risk factors. Kidney Int 2005:67:1576-82.

[58] Adragao T, Herberth J, Monier-Faugere MC, et al. Low bone volume-a risk factor for coronary calcifications in hemodialysis patients. Clin J Am Soc Nephrol 2009;4: $450-5$.

[59] Block GA, Port FK, Re-evaluation of risks associated with hyperphosphatemia and hyperparathyroidism in dialysis patients: recommendations for a change in management. Am J Kidney Dis 2000;35:1226-37.

[60] Ganesh SK, Stack AG, Levin NW, Hulbert-Shearon T, Port FK. Association of elevated serum $\mathrm{PO}(4)$, Ca x PO(4) product, and parathyroid hormone with cardiac mortality risk in chronic hemodialysis patients. J Am Soc Nephrol 2001;12:2131-8.

[61] Naves-Diaz M, Passlick-Deetjen J, Guinsburg A, et al. Calcium, phosphorus, PTH and death rates in a large sample of dialysis patients from Latin America. The CORES Study. Nephrol Dial Transplant 2011;26:1938-47.

[62] Floege J, Kim J, Ireland E, et al. Serum iPTH, calcium and phosphate, and the risk of mortality in a European haemodialysis population. Nephrol Dial Transplant 2011; 26:1948-55.

[63] Coen G, Manni M, Mantella D, et al. Are PTH serum levels predictive of coronary calcifications in haemodialysis patients? Nephrol Dial Transplant 2007;22:3262-7.

[64] Coen G. Calcimimetics, parathyroid hormone, and vascular calcification in chronic kidney disease. Kidney Int 2008:74:1229-31.

[65] Shao JS, Cheng SL, Charlton-Kachigian N, Loewy AP, Towler DA. Teriparatide (human parathyroid hormone (1-34)) inhibits osteogenic vascular calcification in diabetic low density lipoprotein receptor-deficient mice. J Biol Chem 2003; 278:50195-202.

[66] Neves KR, Graciolli FG, dos Reis LM, et al. Vascular calcification: contribution of parathyroid hormone in renal failure. Kidney Int 2007;71:1262-70.

[67] Prie D, Torres PU, Friedlander G. A new axis of phosphate balance control: fibroblast growth factor 23-Klotho. Nephrol Ther 2009;5:513-9.

[68] Hu P, Xuan Q, Hu B, Lu L, Wang J, Qin YH. Fibroblast growth factor-23 helps explain the biphasic cardiovascular effects of vitamin D in chronic kidney disease. Int J Biol Sci 2012;8:663-71. 
[69] Toussaint ND, Pedagogos E, Tan SJ, et al. Phosphate in early chronic kidney disease: associations with clinical outcomes and a target to reduce cardiovascular risk. Nephrology 2012;17:433-44.

[70] Stubbs JR, Liu S, Tang W, et al. Role of hyperphosphatemia and 1,25dihydroxyvitamin $\mathrm{D}$ in vascular calcification and mortality in fibroblastic growth factor 23 null mice. J Am Soc Nephrol 2007;18:2116-24.

[71] Balci M, Kirkpantur A, Gulbay M, Gurbuz OA. Plasma fibroblast growth factor-23 levels are independently associated with carotid artery atherosclerosis in maintenance hemodialysis patients. Hemodial Int 2010;14:425-32.

[72] Faul C, Amaral AP, Oskouei B, et al. FGF23 induces left ventricular hypertrophy. J Clin Invest 2011;121:4393-408.

73] Scialla JJ, Lau WL, Reilly MP, et al. Fibroblast growth factor 23 is not associated with and does not induce arterial calcification. Kidney Int 2013;83:1159-68.

[74] Jean G, Terrat JC, Vanel T, et al. High levels of serum fibroblast growth factor (FGF)23 are associated with increased mortality in long haemodialysis patients. Nephrol Dial Transplant 2009;24:2792-6.

[75] Jean G, Bresson E, Terrat JC, et al. Peripheral vascular calcification in longhaemodialysis patients: associated factors and survival consequences. Nephrol Dial Transplant 2009;24:948-55.

[76] Coen G, De Paolis P, Ballanti P, et al. Peripheral artery calcifications evaluated by histology correlate to those detected by $\mathrm{CT}$ : relationships with fetuin-A and FGF-23. J Nephrol 2011;24:313-21.

[77] Desjardins L, Liabeuf S, Renard C, et al. FGF23 is independently associated with vascular calcification but not bone mineral density in patients at various CKD stages. Osteoporos Int 2012;23:2017-25.

78] Inaba M, Okuno S, Imanishi Y, et al. Role of fibroblast growth factor-23 in peripheral vascular calcification in non-diabetic and diabetic hemodialysis patients. Osteoporos Int 2006;17:1506-13.

[79] Nasrallah MM, El-Shehaby AR, Salem MM, Osman NA, El Sheikh E, Sharaf El Din UA. Fibroblast growth factor-23 (FGF-23) is independently correlated to aortic calcification in haemodialysis patients. Nephrol Dial Transplant 2010;25: 2679-85.

[80] Schoppet M, Hofbauer LC, Brinskelle-Schmal N, et al. Serum level of the phosphaturic factor FGF23 is associated with abdominal aortic calcification in men: the STRAMBO study. J Clin Endocrinol Metab 2012;97:E575-83.

[81] Masai H, Joki N, Sugi K, Moroi M. A preliminary study of the potential role of FGF-23 in coronary calcification in patients with suspected coronary artery disease. Atherosclerosis 2013;226:228-33.

[82] Xiao DM, Wu Q, Fan WF, Ye XW, Niu JY, Gu Y. Effect of serum FGF-23, MGP and fetuin-A on calcium-phosphate metabolism in maintenance hemodialysis patients. Hemodial Int 2013;17(4):483-92.

83] Lee CT, Chua S, Hsu CY, et al. Biomarkers associated with vascular and valvular calcification in chronic hemodialysis patients. Dis Markers 2013;34:229-35.

[84] Parker BD, Schurgers LJ, Brandenburg VM, et al. The associations of fibroblast growth factor 23 and uncarboxylated matrix Gla protein with mortality in coronary artery disease: the Heart and Soul Study. Ann Intern Med 2010;152: $640-8$

85] Morena M, Jaussent I, Halkovich A, et al. Bone biomarkers help grading severity of coronary calcifications in non dialysis chronic kidney disease patients. PLoS One 2012;7:e36175.

86] Massy ZA, Drueke TB. Vascular calcification. Curr Opin Nephrol Hypertens 2013;22: 405-12.

87] Prie D, Urena Torres P, Friedlander G. Fibroblast growth factor 23-klotho: a new axis of phosphate balance control. Med Sci 2009;25:489-95.

[88] Bacchetta J, Cochat P, Salusky IB. FGF23 and klotho: the new cornerstones of phosphate/calcium metabolism. Arch Pediatr 2011;18:686-95.

[89] Lau WL, Leaf EM, Hu MC, et al. Vitamin D receptor agonists increase klotho and osteopontin while decreasing aortic calcification in mice with chronic kidney disease fed a high phosphate diet. Kidney Int 2012;82:1261-70.

90] Hu MC, Kuro-o M, Moe OW. Renal and extrarenal actions of Klotho. Semin Nephrol 2013;33:118-29.

[91] Ketteler M, Bongartz P, Westenfeld R, et al. Association of low fetuin-A (AHSG) concentrations in serum with cardiovascular mortality in patients on dialysis: a cross-sectional study. Lancet 2003;361:827-33.

[92] Oikawa O, Higuchi T, Yamazaki T, Yamamoto C, Fukuda N, Matsumoto K. Evaluation of serum fetuin-A relationships with biochemical parameters in patients on hemodialysis. Clin Exp Nephrol 2007;11:304-8.

[93] Wang AY, Woo J, Wang M, et al. Association of inflammation and malnutrition with cardiac valve calcification in continuous ambulatory peritoneal dialysis patients. J Am Soc Nephrol 2001;12:1927-36.

[94] Schafer C, Heiss A, Schwarz A, et al. The serum protein alpha 2-Heremans-Schmid glycoprotein/fetuin-A is a systemically acting inhibitor of ectopic calcification. J Clin Invest 2003;112:357-66.

[95] Westenfeld R, Schafer C, Kruger T, et al. Fetuin-A protects against atherosclerotic calcification in CKD. J Am Soc Nephrol 2009;20:1264-74

[96] Heiss A, DuChesne A, Denecke B, et al. Structural basis of calcification inhibition by alpha 2-HS glycoprotein/fetuin-A. Formation of colloidal calciprotein particles. J Biol Chem 2003;278:13333-41.

[97] Price PA, Lim JE. The inhibition of calcium phosphate precipitation by fetuin is accompanied by the formation of a fetuin-mineral complex. J Biol Chem 2003;278: 22144-52.

[98] Smith ER, Hanssen E, McMahon LP, Holt SG. Fetuin-A-containing calciprotein particles reduce mineral stress in the macrophage. PLoS One 2013;8:e60904

[99] Reynolds JL, Skepper JN, McNair R, et al. Multifunctional roles for serum protein fetuin-a in inhibition of human vascular smooth muscle cell calcification. J Am Soc Nephrol 2005;16:2920-30.
[100] Chen NX, O'Neill KD, Chen X, et al. Fetuin-A uptake in bovine vascular smooth muscle cells is calcium dependent and mediated by annexins. Am J Physiol Renal Physiol 2007;292:F599-606.

[101] Sage AP, Tintut Y, Demer LL. Regulatory mechanisms in vascular calcification. Nat Rev Cardiol 2010;7:528-36.

[102] Moe SM, Reslerova M, Ketteler M, et al. Role of calcification inhibitors in the pathogenesis of vascular calcification in chronic kidney disease (CKD). Kidney Int 2005 67:2295-304.

[103] Abdel-Wahab AF, Fathy O, Al-Harizy R. Negative correlation between fetuin-A and indices of vascular disease in systemic lupus erythematosus patients with and without lupus nephritis. Arab J Nephrol Transplant 2013;6:11-20.

[104] Jung JY, Hwang YH, Lee SW, et al. Factors associated with aortic stiffness and its change over time in peritoneal dialysis patients. Nephrol Dial Transplant 2010 25:4041-8.

[105] Chen HY, Chiu YL, Hsu SP, Pai MF, Yang JY, Peng YS. Low serum fetuin A levels and incident stroke in patients with maintenance haemodialysis. Eur J Clin Invest 2013 43:387-96.

[106] Marechal C, Schlieper G, Nguyen P, et al. Serum fetuin-A levels are associated with vascular calcifications and predict cardiovascular events in renal transplant recipients. Clin J Am Soc Nephrol 2011;6:974-85.

[107] Jung HH, Baek HJ, Kim SW. Fetuin-A, coronary artery calcification and outcome in maintenance hemodialysis patients. Clin Nephrol 2011;75:391-6.

[108] Manghat P, Souleimanova I, Cheung J, et al. Association of bone turnover markers and arterial stiffness in pre-dialysis chronic kidney disease (CKD). Bone 2011;48: 1127-32.

[109] Hermans MM, Brandenburg V, Ketteler M, et al. Study on the relationship of serum fetuin-A concentration with aortic stiffness in patients on dialysis. Nephrol Dial Transplant 2006;21:1293-9.

[110] Hamano T, Matsui I, Mikami S, et al. Fetuin-mineral complex reflects extraosseous calcification stress in CKD. J Am Soc Nephrol 2010;21:1998-2007.

[111] Tousoulis D, Siasos G, Maniatis K, et al. Novel biomarkers assessing the calcium deposition in coronary artery disease. Curr Med Chem 2012;19:901-20.

[112] Luo G, Ducy P, McKee MD, et al. Spontaneous calcification of arteries and cartilage in mice lacking matrix GLA protein. Nature 1997;386:78-81.

[113] Khavandgar Z, Roman H, Li J, et al. Elastin haploinsufficiency impedes the progression of arterial calcification in MGP-deficient mice. J Bone Miner Res 2013.

[114] Roy ME, Nishimoto SK. Matrix Gla protein binding to hydroxyapatite is dependent on the ionic environment: calcium enhances binding affinity but phosphate and magnesium decrease affinity. Bone 2002;31:296-302.

[115] Sweatt A, Sane DC, Hutson SM, Wallin R. Matrix Gla protein (MGP) and bone morphogenetic protein-2 in aortic calcified lesions of aging rats. J Thromb Haemost 2003; $1: 178-85$

[116] Lomashvili KA, Wang X, Wallin R, O'Neill WC. Matrix Gla protein metabolism in vascular smooth muscle and role in uremic vascular calcification. J Biol Chem 2011;286:28715-22

[117] Schurgers LJ, Uitto J, Reutelingsperger CP. Vitamin K-dependent carboxylation of matrix Gla-protein: a crucial switch to control ectopic mineralization. Trends Mol Med 2013;19:217-26.

[118] Price PA, Toroian D, Lim JE. Mineralization by inhibitor exclusion: the calcification of collagen with fetuin. J Biol Chem 2009;284:17092-101.

[119] Schurgers LJ, Teunissen KJ, Knapen MH, et al. Novel conformation-specific antibodies against matrix gamma-carboxyglutamic acid (Gla) protein: undercarboxylated matrix Gla protein as marker for vascular calcification. Arterioscler Thromb Vasc Biol 2005;25:1629-33.

[120] Murshed M, Schinke T, McKee MD, Karsenty G. Extracellular matrix mineralization is regulated locally; different roles of two gla-containing proteins. J Cell Biol 2004 165:625-30.

[121] Cranenburg EC, Brandenburg VM, Vermeer C, et al. Uncarboxylated matrix Gla protein (ucMGP) is associated with coronary artery calcification in haemodialysis patients. Thromb Haemost 2009;101:359-66.

[122] Schurgers LJ, Barreto DV, Barreto FC, et al. The circulating inactive form of matrix gla protein is a surrogate marker for vascular calcification in chronic kidney disease: a preliminary report. Clin J Am Soc Nephrol 2010;5:568-75.

[123] Schlieper G, Westenfeld R, Kruger T, et al. Circulating nonphosphorylated carboxylated matrix gla protein predicts survival in ESRD. J Am Soc Nephrol 2011;22: 387-95.

[124] Price PA, Faus SA, Williamson MK. Warfarin causes rapid calcification of the elastic lamellae in rat arteries and heart valves. Arterioscler Thromb Vasc Biol 1998;18: $1400-7$

[125] Koos R, Mahnken AH, Muhlenbruch G, et al. Relation of oral anticoagulation to cardiac valvular and coronary calcium assessed by multislice spiral computed tomography. Am J Cardiol 2005;96:747-9.

[126] Schurgers LJ, Spronk HM, Soute BA, Schiffers PM, DeMey JG, Vermeer C Regression of warfarin-induced medial elastocalcinosis by high intake of vitamin $\mathrm{K}$ in rats. Blood 2007;109:2823-31.

[127] Li X, Yang HY, Giachelli CM. BMP-2 promotes phosphate uptake, phenotypic modulation, and calcification of human vascular smooth muscle cells. Atherosclerosis 2008;199:271-7.

[128] Abe E, Yamamoto M, Taguchi Y, et al. Essential requirement of BMPs-2/4 for both osteoblast and osteoclast formation in murine bone marrow cultures from adult mice: antagonism by noggin. J Bone Miner Res 2000;15:663-73.

[129] Yao Y, Bennett BJ, Wang X, et al. Inhibition of bone morphogenetic proteins protects against atherosclerosis and vascular calcification. Circ Res 2010;107:485-94

[130] Roedel EK, Schwarz E, Kanse SM. The factor VII-activating protease (FSAP) en hances the activity of bone morphogenetic protein-2 (BMP-2). J Biol Chem 2013; 288:7193-203. 
[131] Balderman JA, Lee HY, Mahoney CE, et al. Bone morphogenetic protein-2 decreases microRNA-30b and microRNA-30c to promote vascular smooth muscle cell calcification. J Am Heart Assoc 2012;1:e003905.

[132] Lacey DL, Timms E, Tan HL, et al. Osteoprotegerin ligand is a cytokine that regulates osteoclast differentiation and activation. Cell 1998;93:165-76.

[133] Bennett BJ, Scatena M, Kirk EA, et al. Osteoprotegerin inactivation accelerates advanced atherosclerotic lesion progression and calcification in older ApoE-/- mice. Arterioscler Thromb Vasc Biol 2006;26:2117-24.

[134] Collin-Osdoby P, Rothe L, Bekker S, Anderson F, Huang Y, Osdoby P. Basic fibroblast growth factor stimulates osteoclast recruitment, development, and bone pit resorption in association with angiogenesis in vivo on the chick chorioallantoic membrane and activates isolated avian osteoclast resorption in vitro. J Bone Miner Res 2002;17:1859-71.

[135] Bucay N, Sarosi I, Dunstan CR, et al. osteoprotegerin-deficient mice develop early onset osteoporosis and arterial calcification. Genes Dev 1998;12:1260-8.

[136] Morony S, Sage AP, Corbin T, Lu J, Tintut Y, Demer LL. Enhanced mineralization potential of vascular cells from SM22alpha-Rankl (tg) mice. Calcif Tissue Int 2012;91: 379-86.

[137] Zhou S, Fang X, Xin H, Li W, Qiu H, Guan S. Osteoprotegerin inhibits calcification of vascular smooth muscle cell via down regulation of the Notch1-RBP-Jkappa/Msx2 signaling pathway. PLoS One 2013;8:e68987.

[138] Morena M, Dupuy AM, Jaussent I, et al. A cut-off value of plasma osteoprotegerin level may predict the presence of coronary artery calcifications in chronic kidney disease patients. Nephrol Dial Transplant 2009;24:3389-97.

[139] Morena M, Terrier N, Jaussent I, et al. Plasma osteoprotegerin is associated with mortality in hemodialysis patients. J Am Soc Nephrol 2006;17:262-70.

[140] Hwang JJ, Wei J, Abbara S, Grinspoon SK, Lo J. Receptor activator of nuclear factorkappaB ligand (RANKL) and its relationship to coronary atherosclerosis in HIV patients. J Acquir Immune Defic Syndr 2012;61:359-63.

[141] Ozkok A, Caliskan Y, Sakaci T, et al. Osteoprotegerin/RANKL axis and progression of coronary artery calcification in hemodialysis patients. Clin J Am Soc Nephrol 2012; 7:965-73.

[142] Albu A, Fodor D, Bondor C, Craciun AM. Bone metabolism regulators and arterial stiffness in postmenopausal women. Maturitas 2013;76:146-50.

[143] Meneghini M, Regalia A, Alfieri C, et al. Calcium and osteoprotegerin levels predict the progression of the abdominal aortic calcifications after kidney transplantation. Transplantation 2013;96:42-8.

[144] Svensson M, Dahle DO, Mjoen G, et al. Osteoprotegerin as a predictor of renal and cardiovascular outcomes in renal transplant recipients: follow-up data from the ALERT study. Nephrol Dial Transplant 2012;27:2571-5.

[145] Gordin D, Soro-Paavonen A, Thomas MC, et al. Osteoprotegerin is an independent predictor of vascular events in Finnish adults with type 1 diabetes. Diabetes Care 2013;36:1827-33.

[146] Winther S, Christensen JH, Flyvbjerg A, et al. Osteoprotegerin and mortality in hemodialysis patients with cardiovascular disease. Clin Nephrol 2013;80:161-7.

[147] Scialla JJ, Leonard MB, Townsend RR, et al. Correlates of osteoprotegerin and association with aortic pulse wave velocity in patients with chronic kidney disease. Clin J Am Soc Nephrol 2011;6:2612-9.

[148] Aoki A, Murata M, Asano T, et al. Association of serum osteoprotegerin with vascular calcification in patients with type 2 diabetes. Cardiovasc Diabetol 2013;12:11.

[149] Tousoulis D, Siasos G, Maniatis K, et al. Serum osteoprotegerin and osteopontin levels are associated with arterial stiffness and the presence and severity of coronary artery disease. Int J Cardiol 2013;167:1924-8.

[150] Olesen M, Skov V, Mechta M, Mumm BH, Rasmussen LM. No influence of OPG and its ligands, RANKL and TRAIL, on proliferation and regulation of the calcification process in primary human vascular smooth muscle cells. Mol Cell Endocrinol 2012;362:149-56.

[151] Deuell KA, Callegari A, Giachelli CM, Rosenfeld ME, Scatena M. RANKL enhances macrophage paracrine pro-calcific activity in high phosphate-treated smooth muscle cells: dependence on IL-6 and TNF-alpha. J Vasc Res 2012;49:510-21.

[152] Morony S, Tintut Y, Zhang Z, et al. Osteoprotegerin inhibits vascular calcification without affecting atherosclerosis in $\operatorname{ldl}(-/-)$ mice. Circulation 2008;117:411-20.

[153] Helas S, Goettsch C, Schoppet M, et al. Inhibition of receptor activator of NF-kappaB ligand by denosumab attenuates vascular calcium deposition in mice. Am J Pathol 2009;175:473-8.

[154] Samelson EJ, Miller PD, Christiansen C, et al. RANKL inhibition with denosumab does not influence 3-year progression of aortic calcification or incidence of adverse cardiovascular events in postmenopausal women with osteoporosis and high cardiovascular risk. J Bone Miner Res 2014;29:450-7.

[155] Scatena M, Liaw L, Giachelli CM. Osteopontin: a multifunctional molecule regulating chronic inflammation and vascular disease. Arterioscler Thromb Vasc Biol 2007;27: 2302-9.

[156] Speer MY, McKee MD, Guldberg RE, et al. Inactivation of the osteopontin gene enhances vascular calcification of matrix Gla protein-deficient mice: evidence for osteopontin as an inducible inhibitor of vascular calcification in vivo. J Exp Med 2002;196:1047-55.

[157] Jono S, Peinado C, Giachelli CM. Phosphorylation of osteopontin is required for inhibition of vascular smooth muscle cell calcification. J Biol Chem 2000;275: 20197-203.

[158] Wada T, McKee MD, Steitz S, Giachelli CM. Calcification of vascular smooth muscle cell cultures: inhibition by osteopontin. Circ Res 1999;84:166-78.

[159] Qin X, Corriere MA, Matrisian LM, Guzman RJ. Matrix metalloproteinase inhibition attenuates aortic calcification. Arterioscler Thromb Vasc Biol 2006;26:1510-6.

[160] Berezin AE, Kremzer AA. Circulating osteopontin as a marker of early coronary vascular calcification in type two diabetes mellitus patients with known asymptomatic coronary artery disease. Atherosclerosis 2013;229:475-81.
[161] Kadoglou NP, Papadakis I, Moulakakis KG, et al. Arterial stiffness and novel biomarkers in patients with abdominal aortic aneurysms. Regul Pept 2012;179: 50-4.

[162] Kiefer FW, Zeyda M, Gollinger K, et al. Neutralization of osteopontin inhibits obesity-induced inflammation and insulin resistance. Diabetes 2010;59:935-46.

[163] Zheng Y, Wang Z, Deng L, et al. Osteopontin promotes inflammation in patients with acute coronary syndrome through its activity on IL-17 producing cells. Eur J Immunol 2012;42:2803-14.

[164] Bazzichi L, Ghiadoni L, Rossi A, et al. Osteopontin is associated with increased arterial stiffness in rheumatoid arthritis. Mol Med 2009;15:402-6.

[165] Sun J, Xu Y, Dai Z, Sun Y. Intermittent high glucose enhances proliferation of vascular smooth muscle cells by upregulating osteopontin. Mol Cell Endocrinol 2009;313:64-9.

[166] Gadeau AP, Chaulet H, Daret D, Kockx M, Daniel-Lamaziere JM, Desgranges C. Time course of osteopontin, osteocalcin, and osteonectin accumulation and calcification after acute vessel wall injury. J Histochem Cytochem 2001;49:79-86.

[167] Bini A, Mann KG, Kudryk BJ, Schoen F]. Noncollagenous bone matrix proteins, calcification, and thrombosis in carotid artery atherosclerosis. Arterioscler Thromb Vasc Biol 1999;19:1852-61.

[168] van de Loo PGF, Soute BAM, van Haarlem LJM, Vermeer C. The effect of Gla-containing proteins on the precipitation of insoluble salts. Biochem Biophys Res Commun 1987;142:113-9.

[169] Levy RJ, Gundberg C, Scheinman R. The identification of the vitamin K-dependent bone protein osteocalcin as one of the gamma-carboxyglutamic acid containing proteins present in calcified atherosclerotic plaque and mineralized heart valves. Atherosclerosis 1983;46:49-56.

[170] Hunter GK, Hauschka PV, Poole AR, Rosenberg LC, Goldberg HA. Nucleation and inhibition of hydroxyapatite formation by mineralized tissue proteins. Biochem J 1996;317(Pt 1):59-64.

[171] Ducy P, Desbois C, Boyce B, et al. Increased bone formation in osteocalcin-deficient mice. Nature 1996;382:448-52.

[172] Kavukcuoglu NB, Patterson-Buckendahl P, Mann AB. Effect of osteocalcin deficiency on the nanomechanics and chemistry of mouse bones. J Mech Behav Biomed Mater 2009;2:348-54.

[173] Roy ME, Nishimoto SK, Rho JY, Bhattacharya SK, Lin JS, Pharr GM. Correlations between osteocalcin content, degree of mineralization, and mechanical properties of C. carpio rib bone. J Biomed Mater Res 2001;54:547-53.

[174] Idelevich A, Rais Y, Monsonego-Ornan E. Bone Gla protein increases HIF-1alphadependent glucose metabolism and induces cartilage and vascular calcification. Arterioscler Thromb Vasc Biol 2011;31:e55-71.

[175] Flammer AJ, Gossl M, Widmer RJ, et al. Osteocalcin positive CD133 +/CD34-/KDR + progenitor cells as an independent marker for unstable atherosclerosis. Eur Heart J 2012;33:2963-9.

[176] Fadini GP, Albiero M, Menegazzo L, et al. Procalcific phenotypic drift of circulating progenitor cells in type 2 diabetes with coronary artery disease. Exp Diabetes Res 2012;2012:921685.

[177] Osorio A, Ortega E, Torres JM, Sanchez P, Ruiz-Requena E. Biochemical markers of vascular calcification in elderly hemodialysis patients. Mol Cell Biochem 2013; 374:21-7.

[178] Osorio A, Ortega E, Torres JM, Sanchez P, Ruiz-Requena E. Mineral-bone metabolism markers in young hemodialysis patients. Clin Biochem 2011;44:1425-8.

[179] Kim KJ, Kim KM, Park KH, et al. Aortic calcification and bone metabolism: the relationship between aortic calcification, BMD, vertebral fracture, 25-hydroxyvitamin D, and osteocalcin. Calcif Tissue Int 2012;91:370-8.

[180] Harmey D, Hessle L, Narisawa S, Johnson KA, Terkeltaub R, Millan JL. Concerted regulation of inorganic pyrophosphate and osteopontin by akp2, enpp1, and ank: an integrated model of the pathogenesis of mineralization disorders. Am J Pathol 2004;164:1199-209.

[181] Rutsch F, Ruf N, Vaingankar S, et al. Mutations in ENPP1 are associated with 'idiopathic' infantile arterial calcification. Nat Genet 2003;34:379-81.

[182] Johnson K, Polewski M, van Etten D, Terkeltaub R. Chondrogenesis mediated by PPi depletion promotes spontaneous aortic calcification in NPP1-/- mice. Arterioscler Thromb Vasc Biol 2005;25:686-91.

[183] Towler DA. Inorganic pyrophosphate: a paracrine regulator of vascular calcification and smooth muscle phenotype. Arterioscler Thromb Vasc Biol 2005;25:651-4.

[184] Ketteler M, Floege J. Calcification and the usual suspect phosphate: still guilty but there are other guys behind the scenes. Nephrol Dial Transplant 2006;21:33-5.

[185] Murshed M, Harmey D, Millan JL, McKee MD, Karsenty G. Unique coexpression in osteoblasts of broadly expressed genes accounts for the spatial restriction of ECM mineralization to bone. Genes Dev 2005;19:1093-104.

[186] Villa-Bellosta R, Sorribas V. Prevention of vascular calcification by polyphosphates and nucleotides- role of ATP. Circ J 2013;77:2145-51.

[187] Lomashvili KA, Khawandi W, O'Neill WC. Reduced plasma pyrophosphate levels in hemodialysis patients. J Am Soc Nephrol 2005;16:2495-500.

[188] O'Neill WC, Sigrist MK, McIntyre CW. Plasma pyrophosphate and vascular calcification in chronic kidney disease. Nephrol Dial Transplant 2010;25:187-91.

[189] Riser BL, Barreto FC, Rezg R, et al. Daily peritoneal administration of sodium pyrophosphate in a dialysis solution prevents the development of vascular calcification in a mouse model of uraemia. Nephrol Dial Transplant 2011;26:3349-57.

[190] O'Neill WC, Lomashvili KA, Malluche HH, Faugere MC, Riser BL. Treatment with pyrophosphate inhibits uremic vascular calcification. Kidney Int 2011;79:512-7.

[191] Villa-Bellosta R, Sorribas V. Calcium phosphate deposition with normal phosphate concentration. -Role of pyrophosphate. Circ J 2011;75:2705-10.

[192] Lomashvili KA, Monier-Faugere MC, Wang X, Malluche HH, O'Neill WC. Effect of bisphosphonates on vascular calcification and bone metabolism in experimenta renal failure. Kidney Int 2009;75:617-25. 
[193] Zhou S, Fang X, Xin H, Guan S. Effects of alendronate on the Notch1RBPJkappa signaling pathway in the osteogenic differentiation and mineralization of vascular smooth muscle cells. Mol Med Rep 2013;8:89-94.

[194] Balemans W, Ebeling M, Patel N, et al. Increased bone density in sclerosteosis is due to the deficiency of a novel secreted protein (SOST). Hum Mol Genet 2001;10:537-43.

[195] Brunkow ME, Gardner JC, Van Ness J, et al. Bone dysplasia sclerosteosis results from loss of the SOST gene product, a novel cystine knot-containing protein. Am J Hum Genet 2001;68:577-89.

[196] Joiner DM, Ke J, Zhong Z, Xu HE, Williams BO. LRP5 and LRP6 in development and disease. Trends Endocrinol Metab 2013;24:31-9.

[197] Krishnan V, Bryant HU, Macdougald OA. Regulation of bone mass by Wnt signaling. J Clin Invest 2006;116:1202-9.

[198] Robling AG, Niziolek PJ, Baldridge LA, et al. Mechanical stimulation of bone in vivo reduces osteocyte expression of Sost/sclerostin. J Biol Chem 2008;283:5866-75.

[199] Koos R, Brandenburg V, Mahnken AH, et al. Sclerostin as a potential novel biomarker for aortic valve calcification: an in-vivo and ex-vivo study. J Heart Valve Dis 2013;22: $317-25$
[200] Hampson G, Edwards S, Conroy S, Blake GM, Fogelman I, Frost ML. The relationship between inhibitors of the Wnt signalling pathway (Dickkopf-1(DKK1) and sclerostin), bone mineral density, vascular calcification and arterial stiffness in post-menopausal women. Bone 2013;56:42-7.

[201] Szulc P, Bertholon C, Borel O, Marchand F, Chapurlat R. Lower fracture risk in older men with higher sclerostin concentration: a prospective analysis from the MINOS study. J Bone Miner Res 2013;28:855-64.

[202] Morales-Santana S, Garcia-Fontana B, Garcia-Martin A, et al. Atherosclerotic disease in type 2 diabetes is associated with an increase in sclerostin levels. Diabetes Care 2013;36:1667-74

[203] Claes KJ, Viaene L, Heye S, Meijers B, d'Haese P, Evenepoel P. Sclerostin: Another vascular calcification inhibitor? J Clin Endocrinol Metab 2013;98:3221-8.

[204] Sabbagh Y, Graciolli FG, O'Brien S, et al. Repression of osteocyte Wnt/beta-catenin signaling is an early event in the progression of renal osteodystrophy. J Bone Miner Res 2012;27:1757-72. 